\title{
5. SITE 432: NINTOKU SEAMOUNT
}

\author{
Shipboard Scientific Party 1
}

\section{SITE DATA, HOLE 432}

\author{
Date Occupied: 6 August 1977 (2320 Z) (7 August 1977 \\ [1020 L]) \\ Date Departed: 7 August 1977 (0420 Z) (7 August 1977 \\ [1520 L])
}

Time on Hole: 5 hours 0 minutes

Position: $41^{\circ} 20.03^{\prime} \mathrm{N}, 170^{\circ} 22.74^{\prime} \mathrm{E}$

Water Depth (sea level): 1309.8 corrected meters, echo sounding

Water Depth (rig floor): 1319.8 corrected meters, echo sounding

Bottom Felt at: 1320.0 meters, drill pipe

Penetration: 17.5 meters

Number of Holes: 1

Number of Cores: 1

Total Length of Cored Section: 5.5 meters

Total Core Recovery: 3.0 meters

Percentage Core Recovery: 54.5

Oldest Sediment Cored:

Depth sub-bottom: 5.5 meters

Nature: Siltstone and calcareous mudstone

Chronostratigraphy: Paleocene

Measured velocity: $1.6-1.8 \mathrm{~km} / \mathrm{s}$

Basement:

Not reached

Principal Results: Two holes were drilled in what appeared to be perched terrace deposits atop Nintoku Seamount. Section 1-4 encompasses the Eocene/Pliocene hiatus. In Hole 432 we cored the interval 0 to 5.5 meters, and recovered 3 meters of light green unconsolidated pelagic sediments. The sand-sized fraction consists principally of Quaternary planktonic foraminifers deposited above the CCD. The

\footnotetext{
${ }^{1}$ Everett D. Jackson (Co-Chief Scientist), United States Geological Survey, Menlo Park, California; Itaru Koizumi (Co-Chief Scientist), Osaka University, Osaka, Japan; R. James Kirkpatrick, Deep Sea Drilling Project, Scripps Institution of Oceanography, La Jolla, California (now at: University of Illinois, Urbana, Illinois); Gennady Avdeiko, USSR Academy of Sciences, Petropavlovsk-Kamchatsky, USSR; David Clague, Middlebury College, Middlebury, Vermont; G. Brent Dalrymple, United States Geological Survey, Menlo Park, California; Anne-Marie Karpoff, Institut de Geologie, Strasbourg, France; Judith McKenzie, Eidg. Technische Hochschule, Zurich, Switzerland; Arif Butt, Universitat Tubingen, Tubingen, Federal Republic of Germany; Hsin Yi Ling, University of Washington, Seattle, Washington; Toshiaki Takayama, Kanazawa University, Kanazawa, Japan; H. Gary Greene, United States Geological Survey, Menlo Park, California; Jason Morgan, Princeton University, Princeton, New Jersey; and Masaru Kono, University of Tokyo, Tokyo, Japan.
}

recovered foraminifers, nannofossils, and radiolarians suggest a transitional overlying watermass. The bottom sub sheared off while we were attempting to take Core 2.

\section{SITE DATA, HOLE 432A}

Date Occupied: 7 August 1977 (1620 Z) (8 August 1977 [0320 L])

Date Departed: 8 August 1977 (2236 Z) (9 August 1977 [0936 L])

Time on Hole: 29 hours 16 minutes

Position: $41^{\circ} 20.03^{\prime} \mathrm{N}, 170^{\circ} 22.74^{\prime} \mathrm{E}$

Water Depth (sea level): 1309.8 corrected meters, echo sounding

Water Depth (rig floor): 1319.8 corrected meters, echo sounding

Bottom Felt at: 1320.0 meters, drill pipe

Penetration: 74.0 meters

Number of Holes: 1

Number of Cores: 5

Total Length of Cored Section: $\mathbf{3 8 . 0}$ meters

Total Core Recovery: 15.92 meters

Percentage Core Recovery: 42.4

Oldest Sediment Cored:

Depth sub-bottom: 42.1 meters

Nature: Lithified poorly sorted sandstone

Chronostratigraphy: Paleocene

Measured velocity: $2.64-4.55 \mathrm{~km} / \mathrm{s}$

\section{Basement:}

Depth sub-bottom: 74.0 meters

Nature: Basalt

Velocity range: $4.3-5.7 \mathrm{~km} / \mathrm{s}$

Principal Results: Hole 432A was washed down as far as possible to avoid a repetition of the bottom sub failures at the three previous holes. Hard material was first encountered at 39 meters; 3.52 meters of well-consolidated, calcitecemented conglomerate and sandstone, underlain by a thin red clay above basalt, were recovered. The sandstone and conglomerate were crushed, and yielded a very limited fossil assemblage. Such fossils as are recognizable suggest that the coarse sediments are Paleocene and resulted from erosion of a high basaltic island.

Clasts of alkalic basalt, hawaiite, mugearite, and perhaps post-erosional basalts of the Hawaiian type occur in the lithified conglomerates in Cores 1 and 2. Below the lowest sediments, three flow units of basalt were cored. Flow Unit 1 consists of feldspar phyric alkalic basalt whose top appears to have been eroded off, and which has a minimum thickness of 0.6 meters. Flow Unit 2, which has a minimum thickness of 2.0 meters, is petrographically and compositionally similar to Flow Unit 1 . A $10-\mathrm{cm}$ red clay 
soil on the top of Flow Unit 3 is transitional between alkalic basalt and hawaiite; we cored at least 9.0 meters of Unit 3, and were still coring it when the bottom-hole assembly failed at a sub-bottom depth of 74.0 meters. The chemistry and petrography of the basalts recovered at Site 432 show the Nintoku volcano, like Ōjin and Suiko, is of the Hawaiian type. Although we found no tholeiitic basalt, the three flows recovered are similar to those that form the alkalic basalt common on the volcanoes forming the main Hawaiian islands. The vesicular nature of the tops and bottoms of the lava flows, as well as the red soil zones, shows that the flows were erupted subaerially. Studies of paleomagnetism show that the basalts have more stable magnetic properties than the sediments in this hole. We cannot estimate the paleolatitude of formation of Nintoku Seamount from the limited basaltic section obtained there.

\section{BACKGROUND AND OBJECTIVES}

In planning Leg 55, preliminary Sites 55-1 and 55-1A had been selected as drill sites best suited to meet the objectives of the cruise in the central part of the Emperor chain. Both are on terraces, and both appear, on the records of the R/V S.P. Lee, to have at least 200 meters of well-stratified sedimentary rocks above prominent basement reflectors. We did not anticipate coring lagoonal sediments at either site, but contorted acoustic structures near the lip of the terrace on which Site 55-1 is situated suggested that reef debris might be present among the terrace deposits.

After the failures of bottom subs and bending of bumper subs at Site 431 , situated almost precisely at the Site 55-1 location, the cause of failure considered most likely by the cruise operations manager and the drilling superintendent was that the terrace deposits at Site 431 were unsuitable for drilling. Although the strata penetrated seemed soft beneath the thin crust of ironmanganese fragments, they suspected that hard rock dipped away in the subsurface at both Hole 431 and Hole $431 \mathrm{~A}$, causing the bottom-hole assembly to be systematically deflected from the vertical until bending, and ultimately failure, occurred.

We had little choice but to move the Glomar Challenger to another site. Although Site 55-4, about 60 miles north of Site 431, was the most geologically appealing because a good basement reflector indicated about 225 meters of sedimentary cover, it appeared to be a terrace deposit much like that drilled at Site 431. We therefore decided to turn south and occupy Site 55-5, which, according to our previous Lee traverse and our oblique crossing on the Challenger enroute to Site 431, appeared very similar to Site 430 , where we had drilled a successful hole. As at Site 430, however, we had been unable to resolve acoustic basement before arriving on site. The decision to drill near Site 55-5 rather than Site 55-4 was more tactical than scientific.

\section{OPERATIONS}

\section{Pre-Drilling Site Survey}

A single seismic reflection profile across Nintoku Seamount (Figure 1), obtained with a $80-\mathrm{kJ}$ sparker profiler aboard the R/V S.P. Lee, shows the seamount to be a flat-topped or slightly domed guyot (Figure 2).
Two small mounds on the center of the crest may be erosional remnants of volcanic islands that once stood well above sea level and above the surrounding broad, waveeroded platform (Figure 3). Little sedimentary cover is evident in the Lee profiles, except for relatively thin $(0.1 \mathrm{~s})$ wedges of (probable) terrace deposits that fringe the seamount. Acoustic basement is apparently close to the top surface of the seamount in most places, since no well-defined, continuous reflectors can be observed beneath the bubble pulse.

Site 55-5, chosen as an alternate site, is near the outer northwest edge of the seamount on a flat-lying, stratified, sedimentary unit that appears to be about $0.08 \mathrm{~s}$ thick in the Lee profiles (Figure 2). A similar sedimentary feature exists along the southeast edge of the seamount (preliminary Site 55-5A), beneath which a relatively thick ( 0.1 to $0.4 \mathrm{~s})$ wedge of flat-lying, welllayered reflectors crops out along the uppermost part of the seamount's steep southeast flank.

We observed no prominent reef features along the crest of the seamount; reefs could exist in the shallow subsurface and may be masked by the bubble pulse. Along the flanks of the seamount, however, rounded, buttress-like acoustic features suggestive of reefs do exist.

Twenty-four minutes after a satellite fix at $1944 \mathrm{Z}$ on 6 August (0644 L, 7 August) 1977, we intersected the survey track of the R/V S.P. Lee, turned to $152^{\circ}$ true, and slowed to 6 knots. At $2036 \mathrm{Z}(0736 \mathrm{~L})$ we further reduced speed to 4 knots. A satellite fix at $2138 \mathrm{Z}(0838 \mathrm{~L})$ put us at latitude $41^{\circ} 20.15^{\prime} \mathrm{N}$, longitude $170^{\circ} 21.44^{\prime} \mathrm{E}$. We passed about 0.3 miles southwest of proposed Site $55-5$, and at $2204 \mathrm{Z}(0904 \mathrm{~L})$ turned to a course of $322^{\circ}$ true (Figure 1). The seismic profiles across this site are difficult to interpret because of the thin sedimentary cover and the wide bubble pulse, which is almost $0.1 \mathrm{~s}$ long in the Challenger profiles (Figures 4 and 5). Nevertheless, upon the first pass we were able to identify the same morphology seen in the Lee profile, and decided to drill at this site even though acoustic basement was not well defined. From available seismic profiles, we estimated the sedimentary cover to be nearly $0.1 \mathrm{~s}$ thick $(80 \mathrm{~m}$ thick, using a seismic velocity of $1.6 \mathrm{~km} / \mathrm{s}$ ).

At $2230 \mathrm{Z}(0930 \mathrm{~L})$, we dropped the beacon on proposed Site 55-5 as determined by dead reckoning from the $2138 \mathrm{Z}(0838 \mathrm{~L})$ satellite fix; subsequent satellite data show that Site 432 is about 0.4 miles north of proposed Site $55-5$. We continued on course $322^{\circ}$ true at 4 knots for 0.6 miles to obtain a continuous seismic profile over the site. At $2239 \mathrm{Z}$ (0939), we retrieved the overboard geophysical gear and turned the Challenger to $170^{\circ}$ true to acquire the beacon at $2320 \mathrm{Z}(1020 \mathrm{~L})$. As we ran onto the beacon at slow speed, the $3.5-\mathrm{kHz}$ profile (Figure 6) showed about $0.15 \mathrm{~s}$ of layered strata, suggesting the presence of unconsolidated sediments near the surface.

\section{Drilling Operations}

We dropped the beacon at Site 432 at $2230 \mathrm{Z}, 6$ -August (0930 L, 7 August) 1977, and reoccupied the site at $2320 \mathrm{Z}(1020 \mathrm{~L})$, on the flat top of Nintoku Seamount 


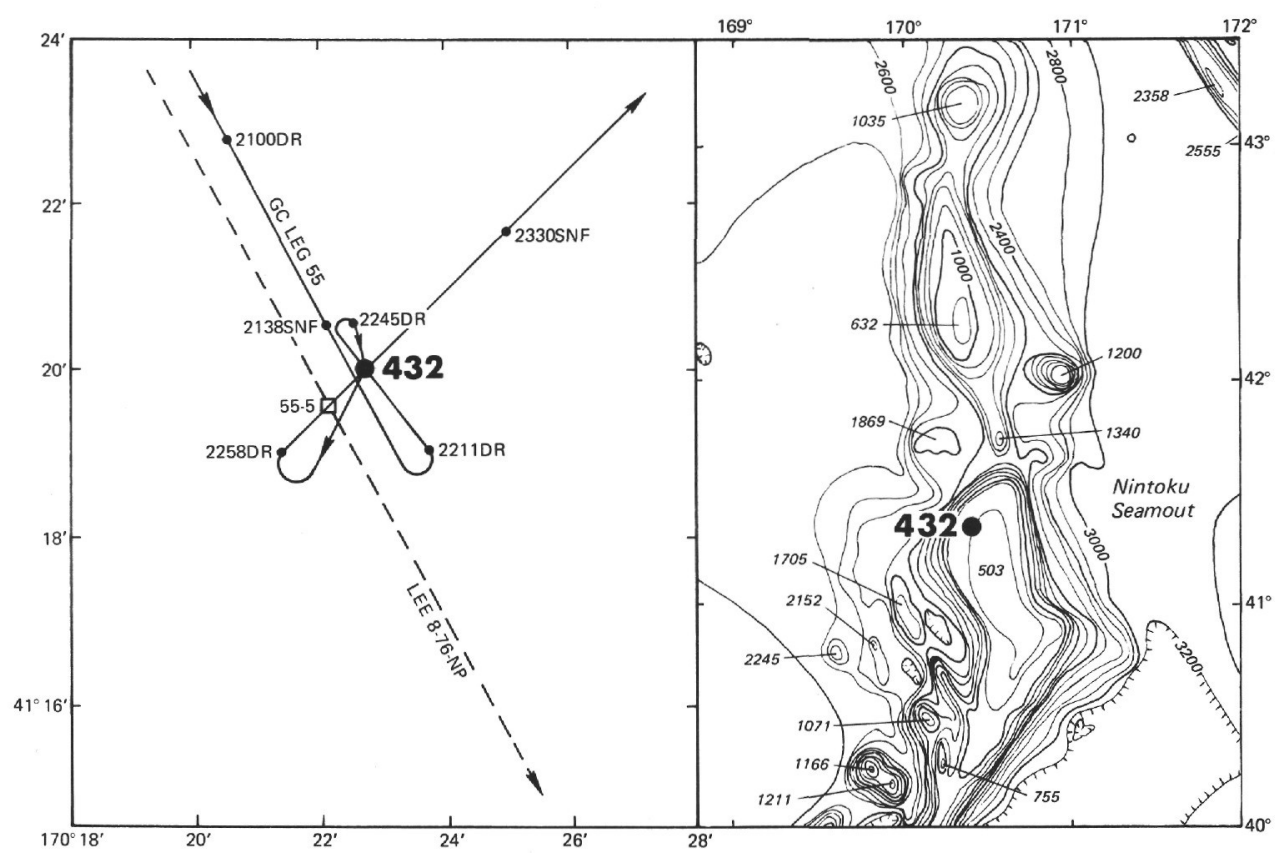

Figure 1. Bathymetry of Nintoku Seamount, and Glomar Challenger Leg 55 and Lee 8-76-NP tracks in the vicinity of Site 432. Depths in fathoms. Bathymetry after Chase et al (1970). Dot shows location of proposed Site 55-5A.

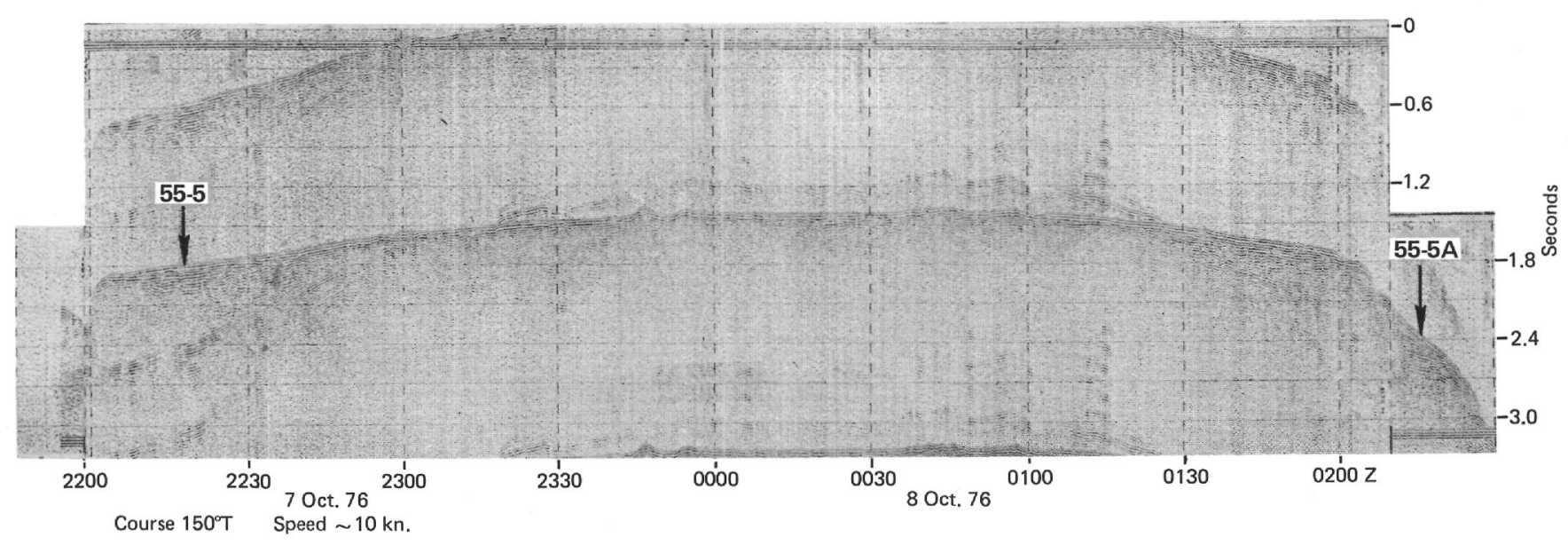

Figure 2. U. S. Geological Survey's S. P. Lee seismic reflection profile, showing location of the originally proposed Sites 55-5 and 55-5A (see Figure 1).

at $41^{\circ} 20.03^{\prime} \mathrm{N}, 170^{\circ} 22.74^{\prime} \mathrm{E}$, very close to the preselected Site $55-5$, at $41^{\circ} 20^{\prime} \mathrm{N}, 170^{\circ} 21^{\prime} \mathrm{E}$. The drill string was run out at once in 1320 meters of water, and Hole 432 was spudded at $0330 \mathrm{Z}(1430 \mathrm{~L})$ on 7 August. The first core was pushed in without rotation, and when recovered, contained 3.0 meters of watery siltstone grading to calcareous mudstone at the base. (See Table 1 for coring summary). An Eastman inclinometer was inserted in the second core to determine the excursions of the bottomhole assembly (BHA) from vertical. The BHA was washed in 5.5 meters without rotation and the pumps were cut; as Core 2 was being pushed in, the drill string at the drilling platform began to vibrate, and at $0440 \mathrm{Z}(1540 \mathrm{~L})$ the BHA broke while the bit was in soft mudstone, at a load of less than 10,000 pounds. The lower bumper sub was bent open, and the bottom sub beneath it was broken cleanly as in the two previous failures at Holes 431 and $431 \mathrm{~A}$. We had lost the bit, bottom sub, core barrel, and inclinometer. At this time we had only three bumper subs and three head subs for core barrels aboard.

After lengthy consultations, all bottom subs on board were measured, and three proved to meet minimum length and thread specifications. We magnafluxed these and made up a new BHA using the good bottom subs and the three remaining bumper subs. We then lowered the lower bumper sub one joint $(9.5 \mathrm{~m})$ to a position only 20 meters above the bit, to insure rapid burial, and removed the "knobby joints" which had 


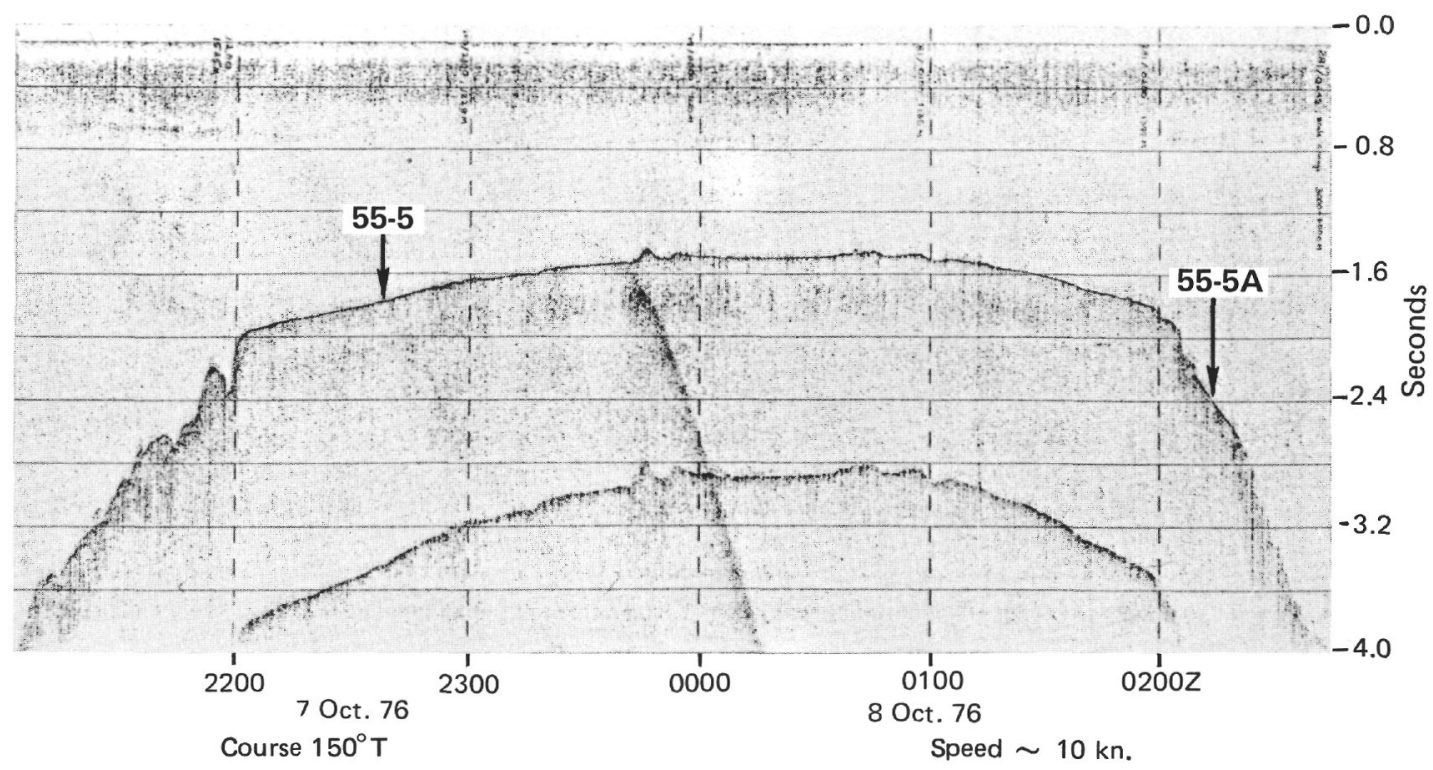

Figure 3. U. S. Geological Survey's S. P. Lee 3.5-kHz profile, showing location of the originally proposed Sites 55-5 and 55-5A.

been added between the BHA and the drill pipe in the Long Beach revision of the drill string. The lower part of the string was thus constructed as near alike the original configuration in use before the July 1977 modifications as possible. Also, the filter on the positioning system computer was bypassed, and monitored for excursions. We then lowered the drill string to 1295 meters ( $25 \mathrm{~m}$ above mudline), where another Eastman inclinometer was locked and retrieved in the core barrel. The inclinometer record showed an inconclusive pattern of marks between $1^{\circ}$ and $4^{\circ}$ from vertical. We lowered the bit and spudded in at $1620 \mathrm{Z}, 7$ August $(0320 \mathrm{~L}, 8$ August), and washed down four joints at less than 5000 pounds load, with the power sub rotating. We continued washing at 13 meters per hour until the bit hit hard sediments 39 meters sub-bottom. We cored Hole $432 \mathrm{~A}$ to 74 meters sub-bottom, and recovered 15.92 meters of firmly consolidated sedimentary rocks and basalt. At about 79 meters (time about $0425 \mathrm{Z}$ [1525 L], 3 August), the bit became stuck, and although circulation was ultimately restored, the string had to be pulled from the hole, resulting in loss of the bit, one bottom sub, the inner core barrel, and the spine of the lower bumper sub. The BHA showed failure at the upper service joints on the lower bumper sub, and not at the bottom sub threads as on the three previous failures. The cause of failure appeared to be caving in the hole during recovery of Core 5 .

At this time we had two bumper subs, two serviceable bottom subs, and two core barrels with head subs; that is, enough materials to make up one shortened BHA. A discussion among the cruise operations manager, the captain, and the two co-chief scientists, regarding the advisability of proceeding to our prime re-entry site at Suiko without reserve drilling capability, or of proceeding at Adak directly for replacement subs, was ended by discovery of a flaw in the shortened BHA. We left Site 432 at 2236 Z, 8 August (0936 L, 9 August)
1977, on a course for Adak, Alaska, having spent a total time of 47 hours 16 minutes on site.

\section{On-Site Positioning}

The satellite navigation data from Site 432 are chronologically summarized in Table 2 . Since Holes 432 and $432 \mathrm{~A}$ were drilled without offset, the data set is broken only to emphasize the fixes which arrived during the drilling of the two holes. Figure 7 shows a consistent pattern of locations received. Hole 432 was spudded while the reported positions appeared to be drifting west-southwest at 122 feet per hour. After the loss of Hole 432, the satellite fixes appear to move randomly but in a much more diffuse pattern than at Hole 430A. The apparent excursions of the positions during the drilling of Hole 432A are as large in magnitude and rate as any observed during the drilling of holes in which the bottom sub twisted off within 30 meters of the surface (unless the position at $2230 \mathrm{Z}$ [0930 L] is spurious). One obvious difference is that the BHA for Hole 432A had been modified. The possibility of the beacon drifting is thus less clear at Site 432 than at Site 431. Uncorrected on-site monitoring of satellite navigation fixes is a crude method for measuring either excursions from beacon or movements of the beacon. All the same, we recommend that beacons be tethered more securely than has been the practice in areas where strong bottom currents are suspected.

After we had drilled Hole 432A, Mr. Melvin Fields, the weatherman on board, suggested another possible explanation for the ship's apparent excursions. He suggested that either diurnal waves in a salinity/water temperature interface above the seamounts, or changing positions of a lens of water with different salinity/temperature characteristics, could have caused refraction of the beacon signal to the ship's hydrophones. We then considered using both a $13.5-$ and a $16-\mathrm{kHz}$ beacon at 


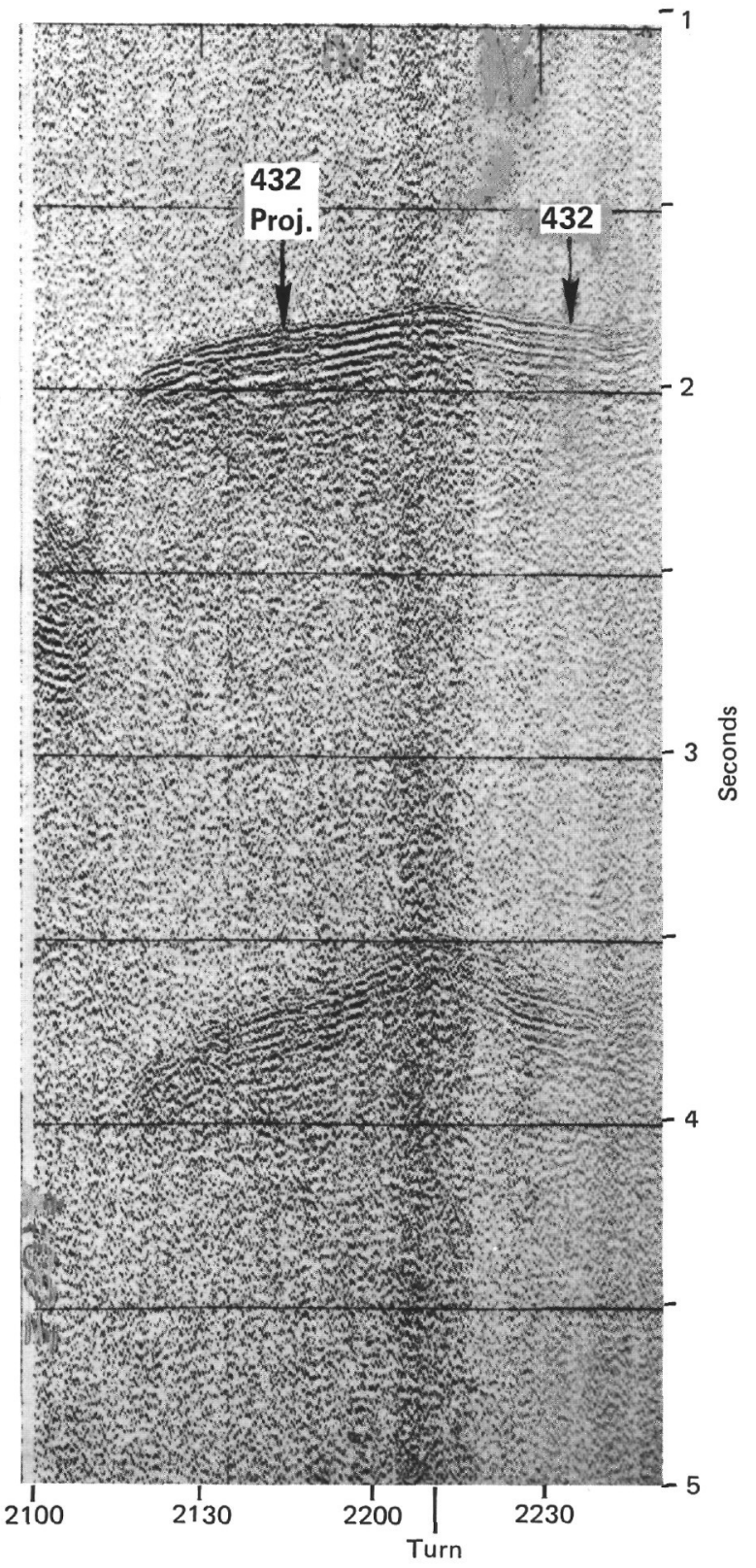

Figure 4. Glomar Challenger 5-s profile across Site 432 (see Figure 1).

the next site, in the hope that their refraction characteristics would be appreciably different.

\section{Post-Drilling Operations}

We left Site 432 at $2236 \mathrm{Z}$ on 8 August (0936 L, 9 August), on a course of $208^{\circ}$ at a speed of 6 knots. At $2258 \mathrm{Z}(0958 \mathrm{~L})$, we turned to $046^{\circ}$ true and passed over the beacon at $2306 \mathrm{Z}(1006 \mathrm{~L})$. In the Challenger seismic reflection profiles obtained on departure from Site 432, the surface of the acoustic basement and the overlying sedimentary unit are not clear (see Figures 8 and 9). The wide bubble pulse and acoustic ringing mask most of the legitimate reflectors. Possible distortion within the bubble pulse at about $0.08 \mathrm{~s}$ (at $1.5 \mathrm{~km} / \mathrm{s}$ this would be $60 \mathrm{~m}$ deep) suggests, however, a probable location for the acoustic basement surface. In this area, acoustic base- ment appears to be irregular, and rises toward the northeast, where it may eventually crop out on the surface of the seamount. At 0012 Z (1112 L), 9 August, we steamed toward Adak, Alaska, to pick up drilling equipment.

\section{Port Call}

We arrived at Adak and rendezvoused with the U.S. Navy tug Mecosta at 1720 Z, 12 August (0420 L, 13 August). By $2030 \mathrm{Z}$ (0730 L), we had transferred four bottom subs and four head subs to the drilling vessel, and discharged two members of the crew, an injured derrickman (David Billington) and a member of the scientific staff (David Clague). We left Adak at $2030 \mathrm{Z}, 12$ August (0700 L, 13 August) and steamed for Site 55-2, where we hoped to drill a multiple re-entry hole.

\section{SEDIMENT LITHOSTRATIGRAPHY}

Although recovery of sediment from Nintoku Seamount was minimal, the distinctive character of the material made it very useful for interpreting the lithostratigraphy of the seamount. At Hole 432, a Quaternary sequence of deep-sea hemipelagic sediments (foraminiferal ooze, sand, and calcareous ooze) caps the surface of the seamount. The Eocene sediments from Hole 432A were cored from much deeper below the surface of the sea floor. These detrital sediments consist of volcanic sandstones, calcareous conglomerates, and fossiliferous volcanic sandstones, which directly overlie the basalt flows, and which represent shallow-water deposition. A red tropical soil horizon, which must have developed subaerially, separates two basalt flows. The following lithologic units are distinguishable:

\begin{tabular}{|c|c|c|c|c|}
\hline Hole & Unit & Lithology & $\begin{array}{l}\text { Core Section, } \\
\text { Interval }(\mathrm{cm})\end{array}$ & $\begin{array}{c}\text { Depth } \\
\text { Below } \\
\text { Sea } \\
\text { Floor }(\mathrm{m})\end{array}$ \\
\hline \multirow[t]{3}{*}{432} & 1 & Foraminiferal ooze & $\begin{array}{l}1-1,2,3 \\
1-4,0-50\end{array}$ & \multirow{3}{*}{$0-5.5$} \\
\hline & 2 & Sand & $\begin{aligned} & 1-4, 50-100 \\
& 120-130\end{aligned}$ & \\
\hline & 3 & Calcareous ooze & $1-4,100-120$ & \\
\hline \multirow[t]{4}{*}{$432 \mathrm{~A}$} & 1 & Volcanic sandstone & $1-1,0-15$ & \multirow[b]{2}{*}{$36.0-41.5$} \\
\hline & 2 & Calcareous conglomerate & $\begin{array}{l}1-1,45-52 \\
2-1,0-10\end{array}$ & \\
\hline & 3 & $\begin{array}{l}\text { Fossiliferous volcanic } \\
\text { sandstone }\end{array}$ & $2-1,20-60$ & \multirow[t]{2}{*}{$41.5-55.0$} \\
\hline & 4 & Red tropical soil & $2, \mathrm{CC}$ & \\
\hline
\end{tabular}

\section{Sediment Description}

\section{Hole 432}

Unit 1 is a grayish brown $(2.5 \mathrm{Y} 5 / 2)$ foraminiferal ooze composed of 95 per cent foraminifers and 5 per cent sand. Palagonite, iron-manganese fragments, quartz, and volcanics make up the sand fraction. The ooze from Section 1-2 contains foraminifers $(60 \%)$, carbonate clasts $(30 \%)$, clay $(5 \%)$, and a mixture $(5 \%)$ of altered basalt, volcanic fragments, quartz, and heavy minerals. With depth in the core, the proportion of foraminifers rela- 


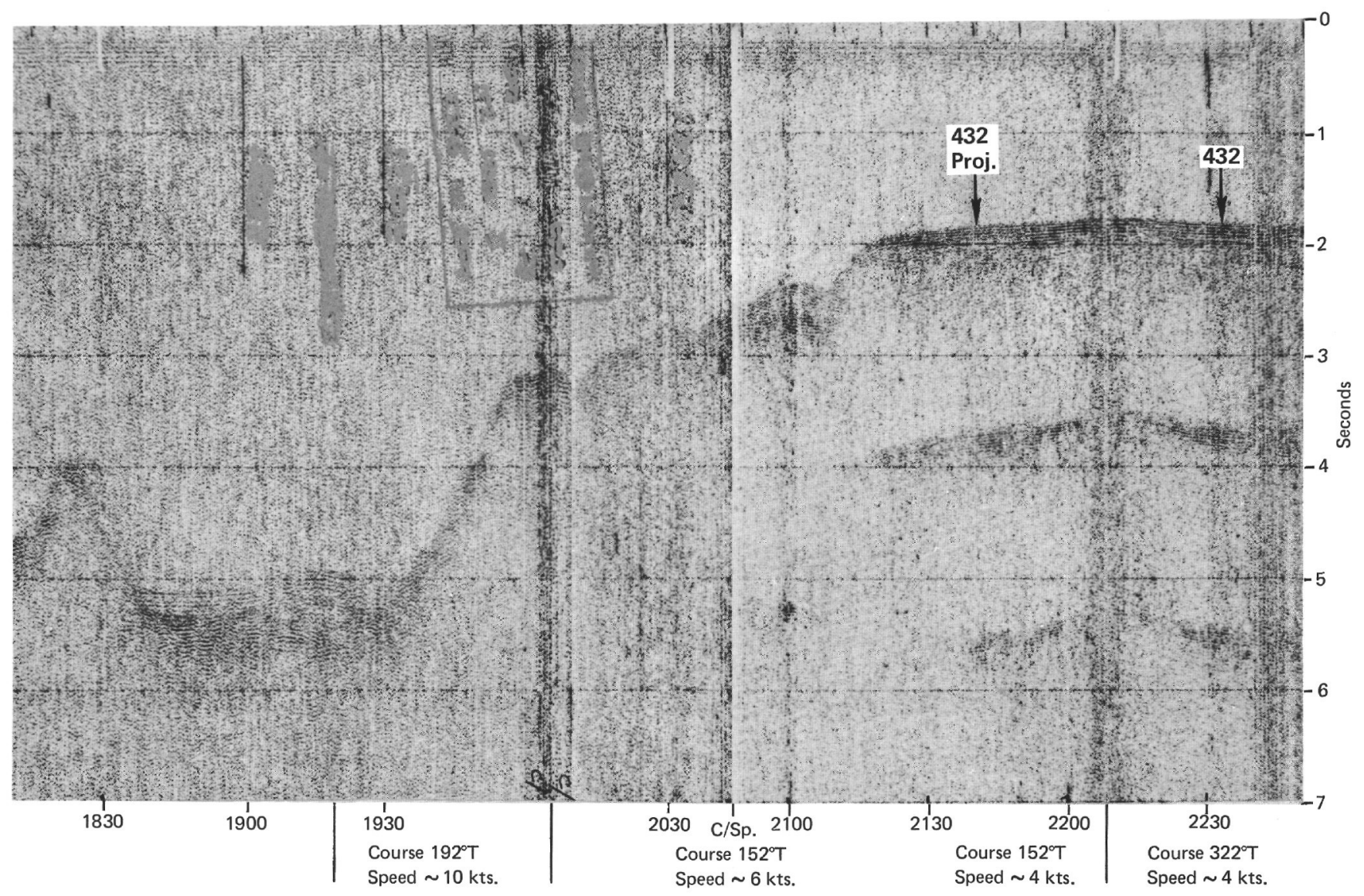

Figure 5. Glomar Challenger 10-s profile across Site 432, showing physiographic features used in locating site (see Figure 1).

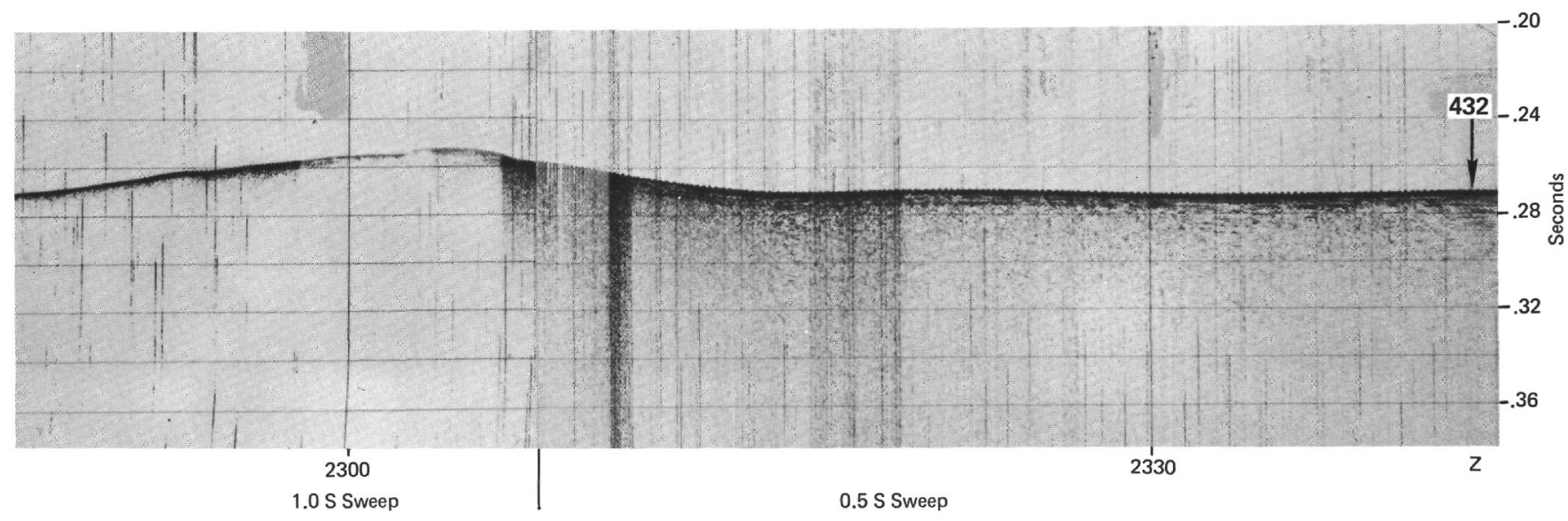

Figure 6. Glomar Challenger 3.5-kHz profile across Site 432, showing the thin cover of unconsolidated sediment.

tive to carbonate clasts decreases. In Section 1-4, the ooze contains carbonates clasts $(40 \%)$, foraminifers $(20 \%)$, Mn micronodules (20\%), nannofossils (5\%), quartz (5\%), clay $(5 \%)$, and volcanic glass $(5 \%)$.

Unit 2 , a very dark grayish brown $(2.5 \mathrm{Y} 3 / 2)$, finegrained volcanic sand, underlies Unit 1 . It is composed of iron-manganese fragments, basalt fragments, quartz, and altered basalt. Microscopically, it consists of car- bonate clasts $(20 \%)$, volcanic fragments $(20 \%)$, quartz $(20 \%)$, Mn micronodules $(15 \%)$, foraminifers $(10 \%)$, and heavy minerals $(5 \%)$.

Unit 3, a calcareous ooze, is interbedded within Unit 2 . It has a light yellowish brown color $(2.5 \mathrm{Y} 6 / 4)$ and is composed of carbonate clasts $(70 \%)$, clay $(10 \%), \mathrm{Mn}$ micronodules $(10 \%)$, quartz $(5 \%)$, and volcanic glass $(5 \%)$. 
TABLE 1

Coring Summary, Site 432

\begin{tabular}{|c|c|c|c|c|c|c|c|}
\hline Core & $\begin{array}{l}\text { Date } \\
\text { (Aug. } \\
\text { 1977) }\end{array}$ & Time & $\begin{array}{l}\text { Depth } \\
\text { from } \\
\text { Drill } \\
\text { Floor } \\
\text { (m) }\end{array}$ & $\begin{array}{c}\text { Depth } \\
\text { below } \\
\text { Sea } \\
\text { Floor } \\
\text { (m) }\end{array}$ & $\begin{array}{l}\text { Length } \\
\text { Cored } \\
\text { (m) }\end{array}$ & $\begin{array}{c}\text { Length } \\
\text { Recov- } \\
\text { ered } \\
\text { (m) }\end{array}$ & $\begin{array}{c}\text { Recov- } \\
\text { ery } \\
(\%)\end{array}$ \\
\hline \multicolumn{8}{|l|}{ Hole 432} \\
\hline 1 & 7 & 1505 & $\begin{array}{l}1320.0- \\
1325.5\end{array}$ & $\begin{array}{l}0.0- \\
5.5\end{array}$ & 5.5 & 3.00 & 5.5 \\
\hline Total & & & & & 5.5 & 3.00 & 5.5 \\
\hline \multirow{5}{*}{ Hole 432A } & & & & & & & \\
\hline & 8 & 0340 & $\begin{array}{l}1320.0- \\
1327.5\end{array}$ & $\begin{array}{l}0.0- \\
7.5\end{array}$ & WASH & & \\
\hline & 8 & 0410 & $\begin{array}{l}1327.5- \\
1337.0\end{array}$ & $\begin{array}{l}7.5- \\
17.0\end{array}$ & WASH & & \\
\hline & 8 & 0430 & $\begin{array}{l}1337.0- \\
1346.5\end{array}$ & $\begin{array}{l}17.0- \\
26.5\end{array}$ & WASH & & \\
\hline & 8 & 0505 & $\begin{array}{l}1346.5- \\
1356.0\end{array}$ & $\begin{array}{l}26.5- \\
36.0\end{array}$ & WASH & & \\
\hline 1 & 8 & 0615 & $\begin{array}{l}1356.0- \\
1361.5\end{array}$ & $\begin{array}{l}36.0- \\
41.5\end{array}$ & 5.5 & 0.30 & 5.5 \\
\hline 2 & 8 & 0745 & $\begin{array}{l}1361.5- \\
1375.0\end{array}$ & $\begin{array}{l}41.5- \\
55.0\end{array}$ & 13.5 & 3.40 & 25.1 \\
\hline 3 & 8 & 1025 & $\begin{array}{l}1375.0- \\
1384.5\end{array}$ & $\begin{array}{l}55.0- \\
64.5\end{array}$ & 9.5 & 3.40 & 36.2 \\
\hline 4 & 8 & 1248 & $\begin{array}{l}1384.5- \\
1391.0\end{array}$ & $\begin{array}{l}64.5- \\
71.0\end{array}$ & 6.5 & 6.30 & 96.9 \\
\hline 5 & 8 & 1425 & $\begin{array}{l}1391.0- \\
1394.0\end{array}$ & $\begin{array}{l}71.0^{-} \\
74.0\end{array}$ & 3.0 & 2.70 & 90.0 \\
\hline Total & & & & & 38.0 & 16.10 & 42.4 \\
\hline
\end{tabular}

TABLE 2

On-Site Satellite Navigation Positions, Site 432

\begin{tabular}{|c|c|c|c|c|c|c|}
\hline Core & Time & Latitude & Longitude & $\begin{array}{l}\text { Satel- } \\
\text { lite } \\
\text { No. }\end{array}$ & Statistics & $\begin{array}{l}\text { Alti } \\
\text { tude } \\
\left(^{\circ}\right)\end{array}$ \\
\hline \multicolumn{7}{|l|}{ Hole 432} \\
\hline 1 & 7 A ug. 0054 & $41^{\circ} 20.041^{\prime} \mathrm{N}$ & $170^{\circ} 22.190^{\prime} \mathrm{E}$ & 20 & Poor & 46 \\
\hline 2 & 0418 & $41^{\circ} 19.975^{\prime} \mathrm{N}$ & $170^{\circ} 22.688^{\prime} \mathrm{E}$ & 12 & Fair & 14 \\
\hline 3 & 0518 & $41^{\circ} 19.949^{\prime} \mathrm{N}$ & $170^{\circ} 22.727^{\prime} \mathrm{E}$ & 46 & $\begin{array}{l}\text { Good } \\
\text { (suspect) }\end{array}$ & 41 \\
\hline 4 & 0656 & $41^{\circ} 19.946^{\prime} \mathrm{N}$ & $170^{\circ} 22.765^{\prime} \mathbf{E}$ & 46 & $\begin{array}{l}\text { Excellent } \\
\text { (suspect) }\end{array}$ & 14 \\
\hline \multicolumn{7}{|l|}{ Hole 432A } \\
\hline 5 & 7 Aug. 0740 & $41^{\circ} 20.035^{\prime} \mathrm{N}$ & $170^{\circ} 22.783^{\prime} \mathrm{E}$ & 19 & Good & 34 \\
\hline 6 & 0932 & $41^{\circ} 20.028^{\prime} \mathrm{N}$ & $170^{\circ} 22.783^{\prime} \mathrm{E}$ & 19 & Excellent & 43 \\
\hline 7 & 1122 & $41^{\circ} 20.027^{\prime} \mathrm{N}$ & $170^{\circ} 22.754^{\prime} \mathrm{E}$ & 14 & Excellent & 30 \\
\hline 8 & 1156 & $41^{\circ} 20.029^{\prime} \mathrm{N}$ & $170^{\circ} 22.736^{\prime} \mathrm{E}$ & 20 & Good & 70 \\
\hline 9 & 1342 & $41^{\circ} 20.010^{\prime} \mathrm{N}$ & $170^{\circ} 22.761^{\prime} \mathrm{E}$ & 20 & Good & 17 \\
\hline 10 & 1616 & $41^{\circ} 20.122^{\prime} \mathrm{N}$ & $170^{\circ} 22.697^{\prime} \mathrm{E}$ & 12 & Poor & 14 \\
\hline 11 & 1948 & $41^{\circ} 19.981^{\prime} \mathrm{N}$ & $170^{\circ} 22.736^{\prime} \mathrm{E}$ & 12 & Fair & 13 \\
\hline 13 & 2230 & $41^{\circ} 20.049^{\prime} \mathrm{N}$ & $170^{\circ} 22.825^{\prime} \mathrm{E}$ & 19 & Fair & 13 \\
\hline 14 & 2418 & $41^{\circ} 20.031^{\prime} \mathrm{N}$ & $170^{\circ} 22.774^{\prime} \mathrm{E}$ & 20 & Good & 64 \\
\hline $\begin{array}{c}15 \\
\text { heading chg }\end{array}$ & $\begin{array}{r}8 \text { A ug. } 0134 \\
0240\end{array}$ & $\begin{array}{l}41^{\circ} 20.037^{\prime} \mathrm{N} \\
200^{\circ} \rightarrow 165^{\circ}\end{array}$ & $170^{\circ} 22.758^{\prime} \mathrm{E}$ & 20 & Good & 22 \\
\hline 16 & 0420 & $41^{\circ} 20.018^{\prime} \mathrm{N}$ & $170^{\circ} 22.694^{\prime} \mathrm{E}$ & 46 & $\begin{array}{l}\text { Good } \\
\text { (suspect) }\end{array}$ & 11 \\
\hline 17 & 0508 & $41^{\circ} 20.038^{\prime} \mathrm{N}$ & $170^{\circ} 22$ & 12 & Excellent & 39 \\
\hline 18 & 0600 & $41^{\circ} 19.997^{\prime} \mathrm{N}$ & $170^{\circ} 22.743^{\prime} \mathrm{E}$ & 46 & $\begin{array}{l}\text { Poor } \\
\text { (suspect) }\end{array}$ & 54 \\
\hline 19 & 0654 & $41^{\circ} 20.036^{\prime} \mathrm{N}$ & $170^{\circ} 22.714^{\prime} \mathrm{E}$ & 12 & Good & 34 \\
\hline 20 & 1054 & $41^{\circ} 20.036^{\prime} \mathrm{N}$ & $170^{\circ} 22.736^{\prime} \mathrm{E}$ & 20 & Excellent & 21 \\
\hline 21 & 1240 & $41^{\circ} 20.042^{\prime} \mathrm{N}$ & $170^{\circ} 22.719^{\prime} \mathrm{E}$ & 20 & Excellent & 54 \\
\hline 22 & 1622 & $41^{\circ} 20.057^{\prime} \mathrm{N}$ & $170^{\circ} 22.703^{\prime} \mathrm{E}$ & 46 & $\begin{array}{l}\text { Fair } \\
\text { (suspect) }\end{array}$ & 15 \\
\hline 23 & 1706 & $41^{\circ} 20$ & $170^{\circ} 22$. & 12 & Poor & 39 \\
\hline 24 & 1800 & $41^{\circ} 19.995^{\prime} \mathrm{N}$ & $170^{\circ} 22.824^{\prime} \mathrm{E}$ & 46 & $\begin{array}{l}\text { Good } \\
\text { (suspect) }\end{array}$ & 63 \\
\hline 25 & 1852 & $41^{\circ} 20$. & 170 & 12 & Good & 33 \\
\hline 26 & 1954 & $41^{\circ} 20.030^{\prime} \mathrm{N}$ & $170^{\circ} 22.723^{\prime} \mathrm{E}$ & 19 & Excellent & 37 \\
\hline
\end{tabular}

\section{Hole 432A}

Unit 1 is a volcaniclastic sandstone, dark grayish brown $(2.5 \mathrm{Y} \mathrm{4/2})$, containing grains of basalt, red weathered volcanics, quartz, feldspar, and olivine. The uniform grain size indicates that the sand was well sorted. In thin section, the sand grains are clay-coated volcanic clasts $(70 \%)$, quartz (5\%), and feldspar (5\%), cemented by calcite $(20 \%)$.

Unit 2 is a hard, well-cemented calcareous conglomerate consisting of angular to rounded epiclastic volcanics (60 to 65\%), carbonate fragments of coralline algae, shell and algal nodules ( 30 to $35 \%$ ), and siliceous grains $(5 \%)$. The size of conglomerate inclusions ranges from sand-sized grains up to pebbles $2 \mathrm{~cm}$ in diameter. In thin section, the conglomerates are composed of trachytic volcanic rocks $(50 \%)$, biogenic carbonate detritus (algal filaments, shells, fecal pellets, foraminifers, and bryozoans; $40 \%)$, quartz $(5 \%)$, and micritic calcite cement $(5 \%)$.

Unit 3 is a size-graded, very dark gray $(2.5 \mathrm{Y} \mathrm{N} 3)$ fossiliferous volcanic sandstone. Within the graded bedding, the finer grained layers are more volcaniclastic and less calcareous than the coarser grained layers, which contain skeletal fragments often totally replaced by recrystallized calcite. Gastropod molds are especially prominent. With depth, the volcanic clast size increases up to $4 \mathrm{~cm}$ before giving way to basalt below. In thin section, the sandstone is composed of sand- to silt-sized volcanic particles (20 to $65 \%$ ) and biogenic carbonate detritus ( 30 to $75 \%$ ) cemented together by micrite calcite $(5 \%)$. The fossil fragments include algal filaments, gastropods, foraminifers, and bryozoans.

Unit 4 is a red tropical soil horizon, yellowish red (5YR 4/6) to dark reddish brown (2.5YR 3/4) to dark brown $(7.5$ YR $3 / 2)$. This sandy claystone is composed of clay $(60 \%)$, hematite $(30 \%)$, quartz $(10 \%)$, and traces of heavy minerals which are sometimes altered.

\section{Discussion}

The incomplete sedimentary history compiled from Holes 432 and $432 \mathrm{~A}$ represents the gradual subsidence of Nintoku Seamount. The red tropical soil horizon between basalt flows resulted from weathering during a time when the island was subaerially exposed. The Eocene sandstones and conglomerates contain components formed in a shallow marine environment. The coarse-grained, rounded, and moderately sorted clasts suggest that the deposits were worked in a high-energy environment. The abundant fossils indicate the presence of a nearby reef complex. The fossiliferous volcanic sandstone (Hole 432A, Unit 3), in particular, strongly resembles shallow-water silts and sandstones cored on Kōkō Seamount (DSDP Site 308) in the southern extension of the Emperor Seamount chain (Larson, Moberly, et al., 1975).

\section{BIOSTRATIGRAPHY}

At Site 432, two holes were drilled, but unfortunately both holes had to be abandoned prematurely because of mechanical failure in the bottom-hole assemblies.

From Hole 432, 5.5 meters of Quaternary foraminiferal ooze containing calcareous nannofossils and siliceous microfossils (radiolarians, silicoflagellates, and diatoms) was recovered.

At Hole $432 \mathrm{~A}$, in order to successfully penetrate into the basaltic basement, the upper 36 meters of sediments 


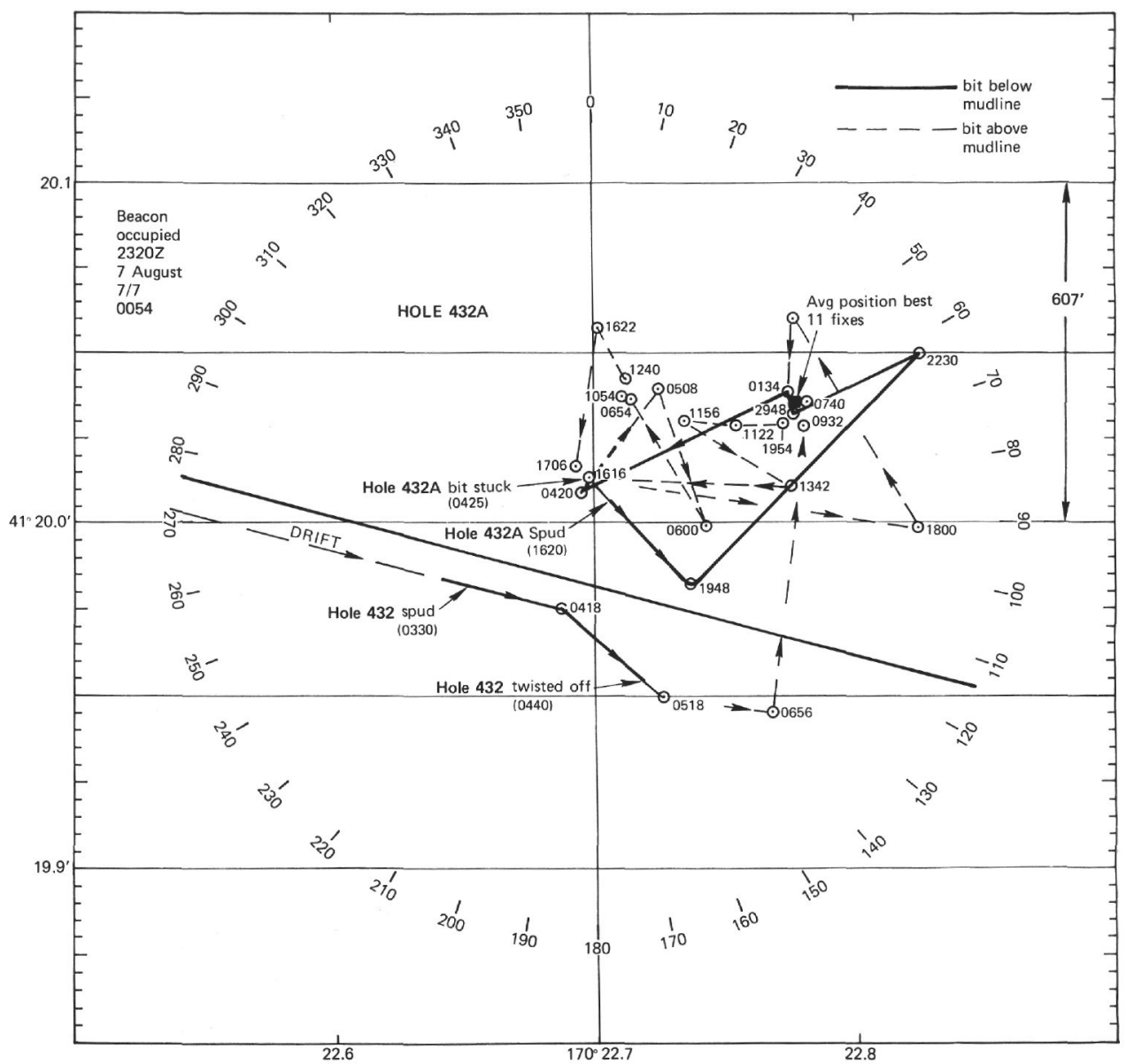

Figure 7. Mercator plot of satellite navigation locations during occupation of Site 432.

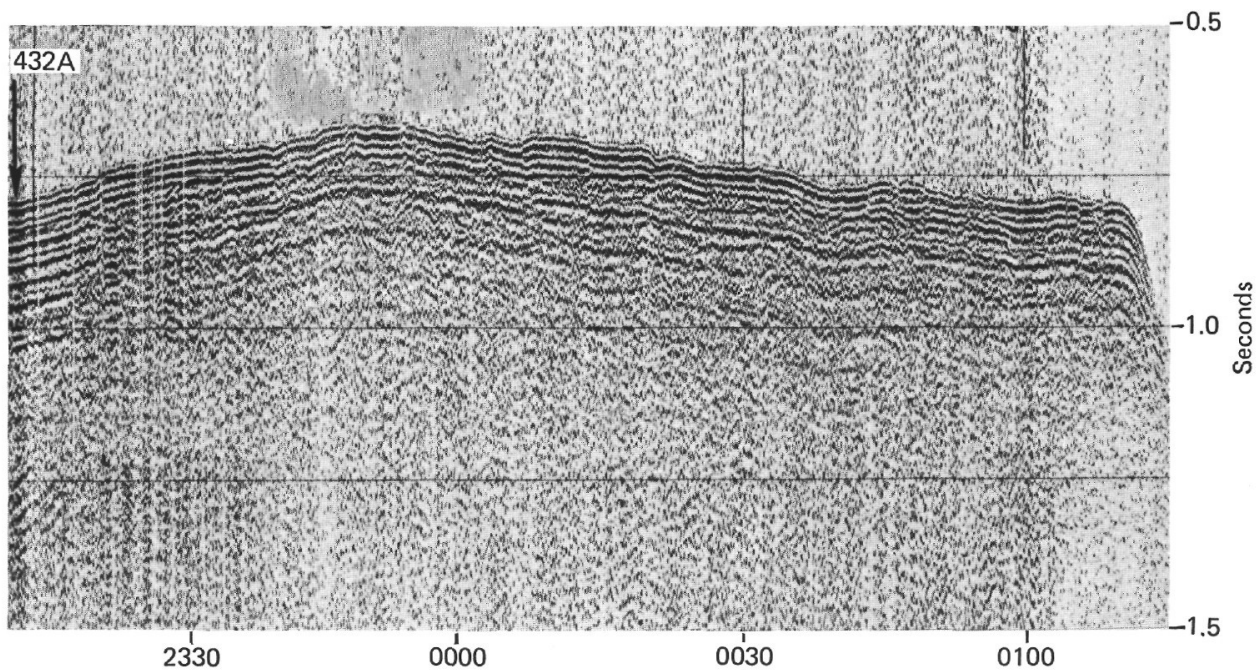

Figure 8. Glomar Challenger 2.5-s seismic profile taken upon departure from Site 432.

was washed. Thirty centimeters of hard calcareous fossiliferous Paleogene sandstone and basalt was recovered in Core 1 and 3.22 meters of conglomeratic basalt and red lateritic clay was recovered in Core 2 before basalts were penetrated in Cores 3,4 , and 5 .

\section{Foraminifers and Other Microfossils}

\section{Hole 432}

Light gray brownish foraminiferal ooze (Core 1, Sections 1-3 and Section 4, 0-50 cm) from Hole 432 consists 


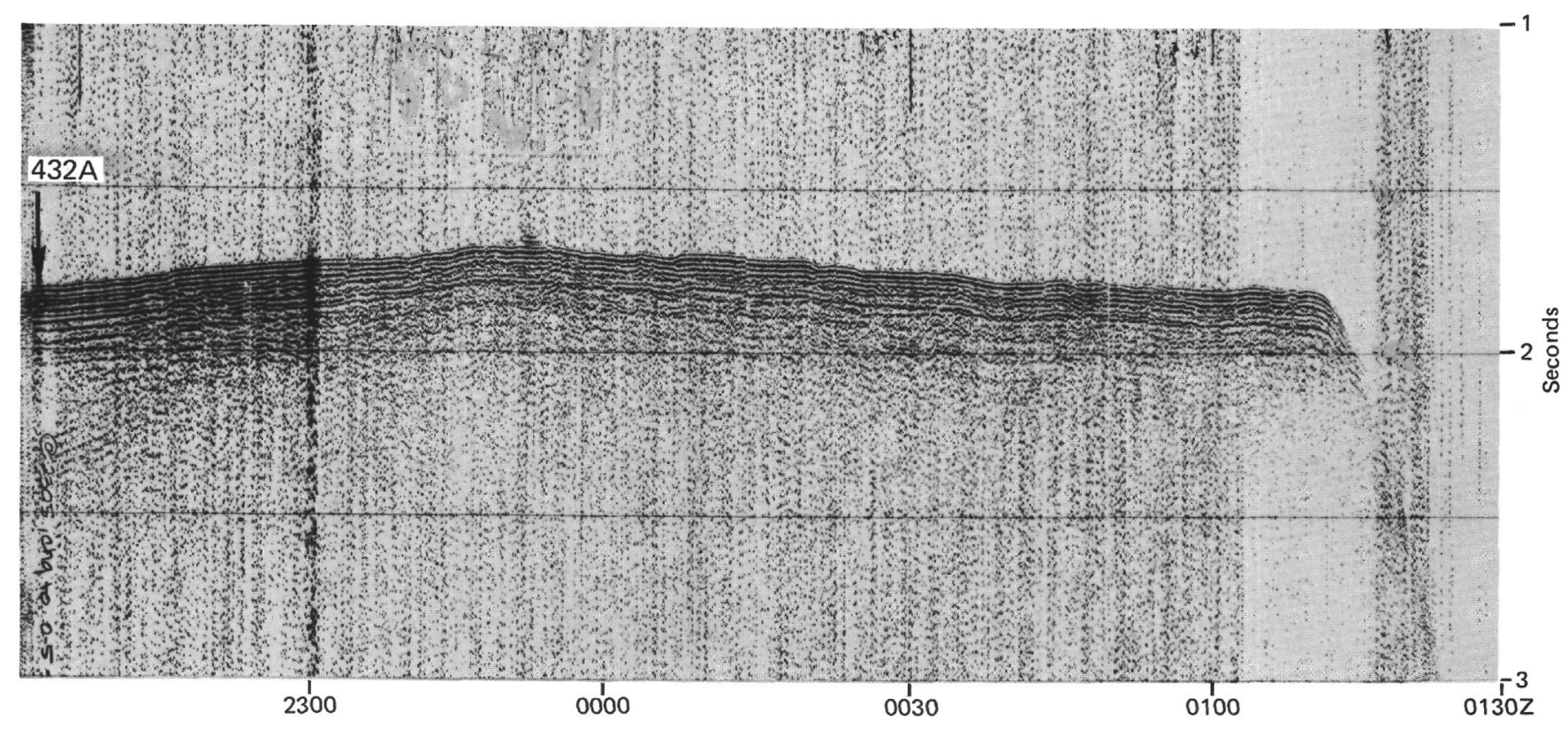

Figure 9. Glomar Challenger 5-s seismic reflection profile taken upon departure from Site 432.

mainly of Quaternary planktonic foraminifers (Globorotalia truncatulinoides Zone). The assemblage in Samples 1-1, 1-7 cm; 1-2, 1-6 cm; and 1-3, 20-25 cm include Globorotalia truncatulinoides (relatively abundant), $G$. inflata, G. scitula, Globigerina bulloides, G. glutinata, Globigerinoides ruber; Neogloboquadrina dutertei, $N$. pachyderma (dominant left-coiled), and Orbulina universa. Abundance and very good preservation of the planktonic species indicate their deposition above the dissolution level. On the other hand, the faunal composition suggests the transitional nature of the overlying water mass. Benthic foraminifers are rare and well preserved, and include upper middle bathyal species such as Cassidulina lomitensis, C. subglobosa, Uvigerina peregrina, U. hispida, U. graciliformis, Pyrgo depressa, and Gyroidina neosoldanii. Some scattered specimens of Cassidulinoides; Carpenteria; Oridorsalis; Quinqueloculina; Praeglobolimina, and Pseudonodosaria are also present in the samples from Core 1 . The number of benthic specimens was apparently diluted by abundant supply of planktonic foraminifers from the overlying water mass.

In Section 1-4, volcanic sand and sandy ooze were recovered in the interval between 50 and $120 \mathrm{~cm}$. Interestingly, these facies (Samples 1-4, 110-115 cm and 1, CC) contain Paleogene planktonic foraminifers such as Globorotalia aequa, G. crassata, and Globigerina mckannai; these planktonic species are moderately well preserved, suggesting an upper Paleocene to lower Eocene chronostratigraphic position. Other faunal components include larger foraminifers such as discocyclinids (Discocyclina $\mathrm{cf}$. cristensis), confirming the above chronostratigraphic determination. These foraminifers are associated with smaller calcareous benthic fossils such as Cibicides, bryozoans, ostracodes, and calcareous algae fragments (see Butt, this volume, and Hagn et al., this volume). These biocomponents suggest shallow-water reef environment of the volcanic sand facies at Hole 432; planktonic foraminifers and discocyclinids, as mentioned above, suggest that a middle Eocene/Pliocene hiatus is represented within Section 1-4.

\section{Hole 432A}

In order to drill the basaltic basement rocks of Nintoku Seamount, we washed down the overlying sedimentary section (partly penetrated at Hole 432 , see above) at Hole 432A. In the Cores 1 and 2, however, hard interbedded sedimentary layers were recovered in addition to basalt. These layers (Section 1-1, 0-15 $\mathrm{cm}$; Section 1-1, 45-52 cm; Section 2-1, 20-60 cm) are made up of conglomerates and coarse-grained volcanic sandstones. Lithic and biogenic components of the sandstone layers in both cores are partly graded and sorted, indicating redeposition by erosional currents. Thin-section study of the samples $(1-1,7-12 \mathrm{~cm} ; 2-1$, $4-7 \mathrm{~cm} ; 2-1,31-33 \mathrm{~cm} ; 2-1,38-41 \mathrm{~cm} ; 2-1,48-55 \mathrm{~cm} ; 2-1$, $56-59 \mathrm{~cm}$ ) reveals that they contain rather abundant microfossils of reef origin. The biogenic constituents include larger foraminifers (discocyclinids, see Hole 432), planktonic foraminifers (Paleogene globorotaliids), and calcareous benthic forms (Lenticulina). They are embedded in sandy matrix, and are probably upper Paleocene to lower Eocene (compare Hole 432). Other embedded fossils of reworked origin include fragments of calcareous algae (Lithothamnium), gastropod and pelecypod shells, ostracodes, bryozoans, echinoidal spines, fish debris, and serpulids. Comparing the results at Hole 432 with those at Hole $432 \mathrm{~A}$, it seems likely that the washed sedimentary section at Hole 432A was Quaternary pelagic ooze and upper Paleocene to lower Eocene reef sand, encompassing perhaps a middle Eocene/Pliocene hiatus. 


\section{Calcareous Nannofossils}

\section{Hole 432}

Surface sediments at Hole 432 are characterized by fairly abundant upper Pleistocene to Holocene (NN 20 Gephyrocapsa oceanica Zone to NN 21 Emiliania huxleyi Zone) calcareous nannofossil occurrences. The species diversity, however, is comparatively low and preservation is moderately good. The assemblage consists of Coccolithus pelagicus (abundant), Cyclococcolithus leptoporus, Gephyrocapsa caribbeanica, $G$. oceanica, Helicopontosphaera wallichii (few), Discolithina japonica, and Helicopontosphaera kamptneri (rare). Recovery of calcareous nannofossils in Sample 1, $\mathrm{CC}$ was poor. Species diversity and population density are very low. Only the dominant Coccolithus pelagicus, several small undiagnostic placoliths, and a single specimen of Braarudosphaera bigelowii were recovered. This assemblage is essentially barren of any age-diagnostic nannofossils.

\section{Hole 432A}

No calcareous nannofossils were recovered from Sample 2, CC.

\section{Radiolarians and Silicoflagellates}

\section{Hole 432}

Common and well-preserved radiolarians of a transitional Quaternary assemblage were recovered from the top of the watery foraminiferal ooze of Section 1-1. Rare but well-preserved silicoflagellates are present. Diatoms also occur. A similar radiolarian assemblage occurs, but silicoflagellates are absent in Sample 1, CC.

\section{Hole 432A}

Radiolarians and silicoflagellates are completely absent in conglomeratic basalt and red clay samples of the core-catcher sample of Core 2 from this hole.

\section{PALEOENVIRONMENT}

The top of Nintoku Seamount (Site 432), which presently lies at about 1320 meters water depth, is capped by a thin layer of Quaternary foraminiferal ooze, reflecting active productivity of microorganisms of the area. In contrast with Ōjin Seamount to the south and with Site 431 to the north, the fine-grained and soupy character of the top sediments $(5 \mathrm{~m}$ below sea floor) at this site may suggest low current velocities or lack of current erosion at the present time. Biogenic components of the sediments include both calcareous and siliceous major microplanktonic groups, and strongly suggest a middle-latitude transitional overlying watermass. Abundant and well-preserved planktonic foraminifers indicate deposition above the CCD.

In tracing the history of Nintoku Seamount, we find that the basaltic mass of the basement probably existed above sea-level during Paleocene time. Tropical soil between basalt flows indicates subaerial weathering of the exposed rocks. The basaltic basement of Hole 432A is capped by the coarse-grained and conglomeratic sand- stone layers. Lithic and biogenic components of these layers are partially graded, which may indicate some submarine debris flow on the subsiding flank of the seamount. Occurrence of larger foraminifers together with bryozoans, gastropods, echinoidal spines, calcareous algae, and serpulids seems to indicate shallow marine fore-reef biota. In addition, the thin sections not uncommonly contain one or two planktonic foraminifers. We believe that these biogenic components do not indicate in-situ shallow-water environment; rather, they were probably reworked by currents and redeposited on the submerged flank of the edifice, and probably derive from an original littoral, photic, warm-water source area. At the same time, the presence of some planktonic foraminifers may indicate an open environment.

With the evidence of subaerial weathering and the shallow Paleocene water depth inferred from the micropaleontological evidence, it is safe to conclude that Nintoku Seamount subsided several hundred meters, but it is unfortunately not possible even to guess now the rate of subsidence, since the sedimentary record encompassing Eocene through at least a part of Pleistocene at both drilled holes is completely absent.

\section{LITHOSTRATIGRAPHY OF VOLCANIC ROCKS (HOLE 432A)}

We recovered from Hole 432A material from three in-place flow units and many fragments of volcanic material from a conglomerate above the flows. Figure 10 illustrates the core recovered and the positions of the flow units. Two of the flows contain abundant plagioclase phenocrysts, and the other contains only rare plagioclase and olivine phenocrysts. The fragments in the conglomerate are mostly aphyric. As in Hole 430A, the boundaries between the flow units are based on vesicular and weathered intervals, which are interpreted to occur at the top and bottom of each flow.

The fragments of volcanic rock recovered from the conglomerate overlying the flows are dense and aphyric. Most are aphanitic, although a cobble from Section 2-1, (Piece 1) has a groundmass of 1 - to $2-\mathrm{mm}$ plagioclase set in a dark matrix of pyroxene and clay.

Flow Unit 1 extends from Section 2-1, Piece 7, where it is depositionally overlain by sandstone, to the broken material in Section 2-1, Piece 13, and is at least $60 \mathrm{~cm}$ thick. Only the top piece, which is in direct contact with the sandstone, is vesicular. If more vesicular material was ever present it has been eroded away. Below the vesicular piece is a massive, relatively fresh-looking interval, and below this a more vesicular (about 10\% vesicles) and altered flow bottom. The vesicles in the top part of the flow are generally 2 to $5 \mathrm{~mm}$ in diameter, but range up to $20 \mathrm{~mm}$. Most are filled or lined with either calcite or dark gray (olive-green when powdered) clay. Near the bottom of the flow the vesicles are 2 to $3 \mathrm{~mm}$ in diameter, and are either filled with the same dark clay as near the top, a light green clay, or a brown clay, or are lined with purple, light green, or white clay. Flow Unit 1 is plagioclase phyric with 10 to 15 per cent phenocrysts; these are tabular and usually about $10 \mathrm{~mm}$ long, al- 


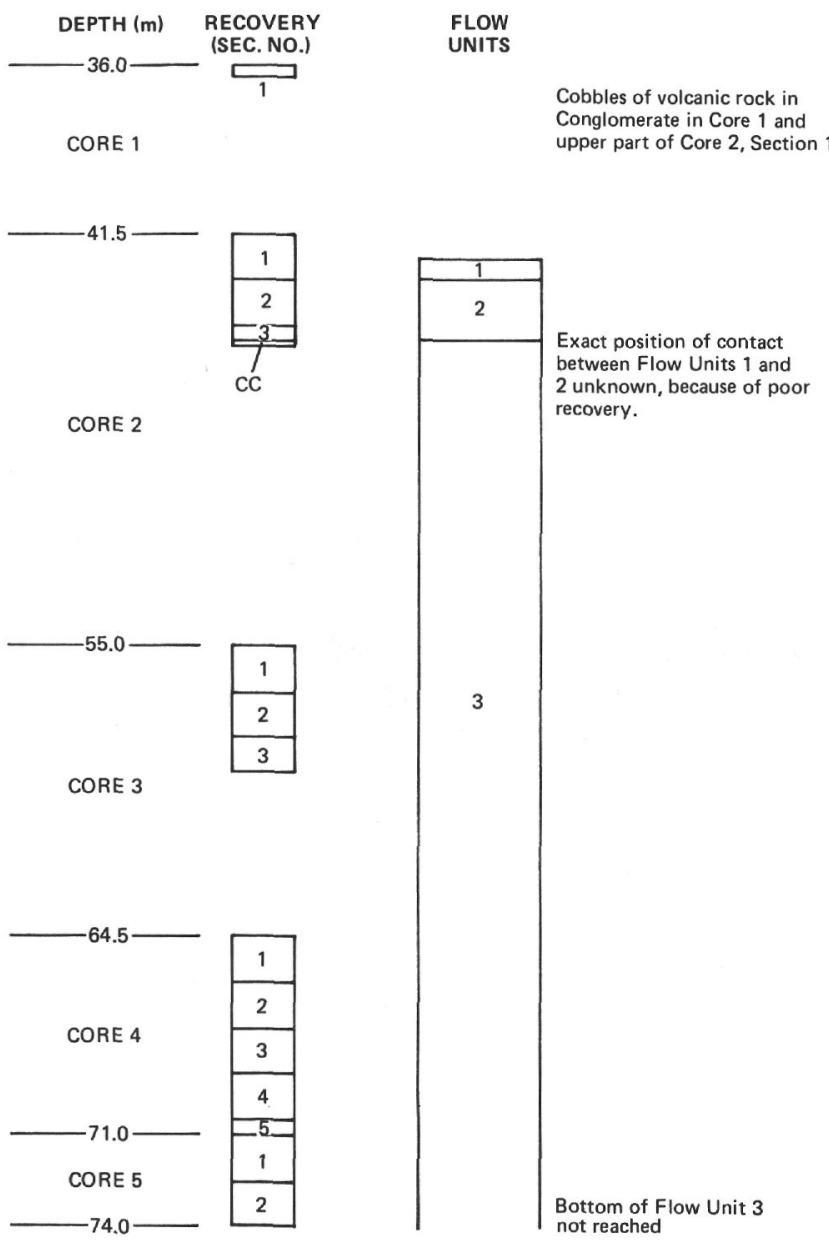

Figure 10. Volcanic flow units, with coring and recovery summary.

though some are up to $15 \mathrm{~mm}$ long, and many appear to contain dark inclusions. The groundmass is diabasic, with about 50 per cent plagioclase (mostly 1 to $2 \mathrm{~mm}$ long) set in a matrix of pyroxene, opaque oxides, and dark alteration product.

Flow Unit 2, extending from Section 2-1, Piece 13, to Sample 2, CC, Piece 2 (minimum thickness $2 \mathrm{~mm}$ ), also consists of plagioclase phyric basalt with a few altered olivine phenocrysts. In overall structure it is very similar to the complete flow units recovered in Hole 430A. The upper part of the flow is altered and vesicular. The vesicles average $4 \mathrm{~mm}$, although some are as large as 20 $\mathrm{mm}$. Below this a massive zone extends to Section 2-3, Piece 13, and below that is an altered and vesicular flow bottom. The vesicles in the bottom average about $3 \mathrm{~mm}$ in diameter. Near the top of the massive center there are three large calcite-filled veins or vugs which extend across the core. The plagioclase phenocrysts in Flow Unit 2 are very similar to those in Flow Unit 1, and range from 1 to $8 \mathrm{~mm}$. There are also a few iddingsitized $1-\mathrm{mm}$ olivine phenocrysts. As in Flow Unit 1, the groundmass in Flow Unit 2 is diabasic, with laths of plagioclase 1 to $3 \mathrm{~mm}$ long set in a matrix of pyroxene, iddingsitized olivine, and dark clay, even in the freshest part of the flow.
At the boundary between Flow Units 2 and 3 is a well-developed 10 -cm-thick red to red-brown clay horizon (Sample 2, CC). Flow Unit 3 extends from here to the bottom of the hole (minimum thickness $9 \mathrm{~m}$ ). The bottom of Flow Unit 3 was not reached. Beneath the clay, the top of Flow Unit 3 is extensively altered to redbrown. Most of this altered material is massive, although some pieces at the very top contain up to 20 per cent 1 - to 5-mm vesicles. Below this the flow is massive, and becomes progressively less altered downward to the central and lower part of Section 3-2, where it is gray and fresh. Then it becomes progressively more altered down to the top of Core 4, beneath which point the alteration is relatively constant. The bulk of the material is gray-brown; along cracks it is brown and extensively altered. The flow is massive throughout, except for four or five rows of flattened ( $1 \mathrm{~mm}$ by 20 to $30 \mathrm{~mm}$ ) vesicles in the central and lower part of Section 4-3 and a few local 2- to $3-\mathrm{mm}$ clay-lined vesicles. Flow Unit 3 is sparsely phyric with about 1 per cent 2 - to $10-\mathrm{mm}$ phenocrysts of plagioclase and 1-mm phenocrysts of olivine (less than 1\%). Some of the olivine, especially in Section $3-2$, is fresh. The groundmass is finer grained than in the other flow units in this hole. Near the top it is aphanitic. It coarsens downward, and beginning in Section 4-1 consists of $0.5-$ to $1-\mathrm{mm}$ plagioclase laths set in a dark matrix of olivine, pyroxene, opaques, and clay. In many pieces even the groundmass olivine is fresh. The texture remains essentially the same to the bottom of the hole.

\section{PETROGRAPHY (HOLE 432A)}

Hole $432 \mathrm{~A}$ penetrated three basalt flows and an overlying pebble conglomerate containing rounded volcanic clasts.

\section{Clasts from Conglomerate}

Most of the pebbles in the conglomerate ( 0.2 to 15 $\mathrm{cm}$ ) are moderately to severely altered, but some of the larger clasts are relatively fresh. Few, if any, of the clasts appear to have been derived from the three recovered underlying flows. A large clast was cored in Sample $1-1,30-40 \mathrm{~cm}$. This clast is a massive hawaiite with subtrachytic texture, and is composed almost entirely of plagioclase laths $(60 \%)$ and both fresh $(15 \%)$ and altered $(20 \%)$ glass. A second clast recovered in Sample $2-1,4-7 \mathrm{~cm}$ is similar, except that the texture is intersertal to hyalophitic and the glass is totally altered to clays. In addition, this specimen contains very rare titanaugite, long acicular apatite crystals, and a trace of rutile(?). This cobble is best classified as transitional between alkalic basalt and hawaiite. A third large clast was recovered between 10 and $20 \mathrm{~cm}$ in Section 2-1. This clast has subtrachytic texture, and is composed of plagioclase $(60 \%)$, olivine altered to iddingsite $(15 \%)$, magnetite with abundant ilmenite exsolution (15\%), and interstitial clays after glass $(\mathbf{1 0 \%})$. This clast most closely resembles a mugearite. Several distinctive small clasts occur in the conglomerate at the top of Core 2 (Sample 2-1, 2-4 cm). The first of these pebbles is a 
hawaiite that contains some dark purple titanaugite, abundant apatite and zeolites, and a trace of red-brown amphibole (kaersutite). Similar rocks, from a dredge on an unnamed seamount west of Midway, have been described by Clague (1974). On the basis of pyroxene compositional data, the dredged samples were inferred to be chemically similar to post-erosional basalts (Fodor et al., 1975).

\section{Flow Unit 1}

Flow Unit 1 is highly altered except in a short section between about 90 and $110 \mathrm{~cm}$ in Section 2-1. The rock is a plagioclase phyric alkalic basalt with intersertal to diabasic texture and about 5 per cent large zoned plagioclase phenocrysts (to $1 \mathrm{~cm}$ ). The groundmass is composed of plagioclase laths $(45 \%)$, titanaugite $(20 \%)$, nearly homogeneous titanomagnetite $(\mathbf{7 \%})$, completely altered olivine $(5 \%)$, clays secondary after glass $(20 \%)$, a trace of apatite, and some interstitial carbonate $(3 \%)$. Near the altered base of Flow Unit 1 (Sample 2-1, $132-135 \mathrm{~cm})$, the basalt is nearly totally altered, and the only primary phases remaining are the cores of laths and phenocrysts of plagioclase.

\section{Flow Unit 2}

Flow Unit 2 is a plagioclase phyric alkalic basalt similar to Flow Unit 1, but contains more plagioclase phenocrysts $(\sim 10 \%)$ and more iddingsitized olivine microphenocrysts. More intergranular titanaugite (about $20 \%$ ) is present than in the upper part of the flow. Both samples contain 1 to 2 per cent round vesicles lined with brown clays.

\section{Flow Unit 3}

Flow Unit 3 is distinguished by an overlying red soil horizon in Sample 2, CC. Only 12 meters of this flow was recovered. This flow unit is massive, and the grainsize distribution indicates that the center of the flow was not reached. The reddish altered upper zone of the flow grades downward to less altered basalt, and by the top of Section 3-2, the recovered rock is a fresh massive gray basalt. A thin section from Sample 3-3, 106-108 cm contains about 1 per cent greenish interstitial clays. The basalt from this part of Flow Unit 3 is by far the least altered basalt recovered from either Hole 430A or Hole 432A. In Section 3-2, the basalt has an intergranular texture and is very fine grained, with an average grain size of about $0.05 \mathrm{~mm}$. The groundmass contains about 60 per cent plagioclase laths, 20 per cent clinopyroxene, 10 per cent homogeneous titanomagnetite, 5 per cent olivine (mostly fresh), and a trace of an unidentified zeolite (analcime?). Phenocrysts of olivine and plagioclase are also present, but rare.

Toward the flow interior, the texture changes, but the mineralogy stays much the same. In Sample 4-2, 15-17 $\mathrm{cm}$, the texture is subophitic to intersertal. The clinopyroxene is titanaugite, and forms subophitic crystals as long as $0.6 \mathrm{~mm}$. A modal count of this thin section is given in Table 3 . Flow Unit 3 is an alkalic to strongly alkalic basalt, judging by the titaniferous composition of the clinopyroxene and the presence of apatite,
TABLE 3

750-Point Modal Count of Sample 2-2, 15-17 cm (Flow Unit 3)

Comments

\begin{tabular}{|c|c|c|}
\hline \multicolumn{3}{|l|}{ Phenocrysts } \\
\hline Olivine & 2 & Altered to clays and calcite \\
\hline Plagioclase & 1 & Resorbed, zoned \\
\hline \multicolumn{3}{|l|}{ Gioundmass } \\
\hline Olivine & 3 & Altered to clays, very rare fresh cores \\
\hline Plagioclase & 47 & $0.3-\mathrm{mm}$ laths \\
\hline Clinopyroxene & 20 & Subophitic, pale brown \\
\hline Titanomagnetite & 10 & \\
\hline A patite & 1 & \\
\hline Biotite & 1 & $\begin{array}{l}\text { Pleochroism: colorless to dark red- } \\
\text { dish brown }\end{array}$ \\
\hline Rutile(?) & $\ll 1$ & \\
\hline Vesicles & $<1$ & \\
\hline \multicolumn{3}{|l|}{ Alteration } \\
\hline Carbonate & 1 & Inter stitial \\
\hline Zeolites & 3 & $\mathrm{RI}<$ plagioclase \\
\hline Clays & 11 & Replacing glass \\
\hline Total & $\overline{100}$ & \\
\hline
\end{tabular}

biotite, and zeolites. This sample has an average grain size of about $0.4 \mathrm{~mm}$.

Farther toward the flow interior (Sample 4-5, 120-122 $\mathrm{cm})$, the texture become ophitic and the clinopyroxene crystals reach $1.5 \mathrm{~mm}$ in length. The basalt becomes slightly coarser grained, but contains even more secondary clay than in the finer grained portions of the flow. Near the bottom of the recovered portion of Flow Unit 3 , the ophitic clinopyroxene crystals develop further and are as large as $2 \mathrm{~mm}$. Throughout Flow Unit 3 the titanomagnetite if unexsolved and unaltered. The olivine present is either fresh, rimmed by greenish clays, or totally replaced by greenish clays. Toward the bottom of the recovered portion of the unit, the grain size increases and the percentage of pyrite also appears to increase.

\section{Comparison of Flows}

Flow Units 1 and 2 are quite similar; both are plagioclase-phyric alkalic basalt flows. The top of Flow Unit 1 apparently was eroded away before deposition of the overlying sandstone unit. The soil horizon between Flow Units 2 and 3 indicates that a considerable period elapsed between the eruption of these two units, and that the eruption of all three flows occurred subaerially.

The olivine microphenocrysts are altered to iddingsite, and the titanomagnetite is extensively exsolved in Flow Units 1 and 2, indicating highly oxidizing conditions. In Flow Unit 3, the olivine is altered to green clays and the titanomagnetite is unexsolved and unaltered, suggesting crystallization under less oxidizing conditions.

\section{Classification}

The clasts recovered in Sections 1-1 and 1-2 are all alkalic differentiates most closely resembling Hawaiian hawaiites and mugearites. Several of the smaller clasts that contain biotite or amphibole may be differentiated from post-erosional basalts similar to the Honolulu or Koloa volcanic series (Macdonald, 1968) or to those 
erupted on an unnamed seamount west of Midway (Clague et al., 1975; Clague, 1974). The titanium-rich composition of the clinopyroxene suggests post-erosional alkalic basalt rather than post-caldera stage alkali basalt. The flows are all alkali basalts. The feldspar-phyric basalts recovered in Flow Units 1 and 2 are unusual, although similar basalts are occasionally found in the post-caldera alkalic series on the Hawaiian Islands (Macdonald, 1968). Flow Unit 3 appears most similar to post-erosional alkali basalt because of the titanaugite, biotite, and zeolites and the abundance of apatite.

\section{ALTERATION (HOLE 432A)}

\section{Flow Units 1 and 2}

The mineralogy, composition, degree of crystallization, and degree of alteration of Flow Units 1 and 2 are nearly the same. For the most part, the alteration depends on stratigraphic position within the two flow units.

In Flow Unit 1 there is a massive flow interior (Section 2-1, 61-108 cm) with an oxidized vesicular bottom (Section 2-1, 110-148 cm). In Flow Unit 2 there is a vesicular oxidized top (Section 2-2, 0-45 $\mathrm{cm}$ ) underlain by a massive flow interior (Section 2-2, 45-119 cm), a partially oxidized flow interior (Section $2-2,120 \mathrm{~cm}$ to Section 2-3, $50 \mathrm{~cm}$ ), and a vesicular oxidized bottom (Section 2-3, 50-67 cm to Section 2, CC, Pieces 1 and 2).

Plagioclase phenocrysts and laths from the massive flow interiors are usually fresh, although glass inclusions are altered to clay minerals. Plagioclase from the top and bottom oxidized zones is more altered (up to $30 \%$ ), usually to clays, but sometimes to carbonate.

Olivine is completely altered to iddingsite and clays. Iddingsite after olivine is more abundant in the top and bottom oxidized zones, where clay is all but absent; in the less oxidized massive interiors of flows, olivine is usually altered to clays and, in small degree, to iddingsite.

Clinopyroxene is usually fresh, but sometimes slightly altered in the oxidized zones.

Interstitial glass (5 to $10 \%$ ) is completely altered to clay minerals. Near some carbonate veins, carbonate replaces glass.

Vesicles from the flow bottoms are partially or completely filled by clay minerals, and in some cases by carbonate. Vesicles at the top of Flow Unit 2 are generally only lined or partially filled by clay minerals. The central parts of fractures are commonly filled with carbonate, separated from the basaltic walls by clay minerals. Carbonate veins up to $3 \mathrm{~cm}$ thick occur. Oxidized zones near veins and fractures are not generally more than 2 or $3 \mathrm{~cm}$ thick.

\section{Flow Unit 3}

Flow Unit 3 consists of the following:

1) An oxidized flow top (Section 3-1, 0-100 cm) with a few vesicles near the top (Piece 1). The oxidation decreases down the section.

2) A slightly oxidized zone (Section $3-1,100 \mathrm{~cm}$ to Section 3-2, $20 \mathrm{~cm}$ ).
3) Fresh massive basalt (Section $3-2,20 \mathrm{~cm}$ to $\mathrm{Sec}-$ tion $3-3,20 \mathrm{~cm}$ ).

4) Fresh basalt with some thin $(0.1$ to $1.0 \mathrm{~cm})$ clayfilled veins (Section 3-3, 30-120 cm).

5) Slightly more fractured basalt, with oxidation along the fractures (Section 4-1, $0 \mathrm{~cm}$ to Section 4-3, 67 $\mathrm{cm})$.

6) Basalt with horizontal lines of elongated vesicles (Section 4-3, 67-135 cm).

7) Fresh basalt with some fractures (Section 4-3, 135 $\mathrm{cm}$ to Section $5-2,150 \mathrm{~cm}$ ).

Although the grain size of the unit is less than that of Flow Units 1 and 2, the degree of alteration is considerably less, especially in the nonoxidized interior.

Plagioclase phenocrysts (rare), laths, and microlites are fresh, except for minor alteration to clay minerals in oxidized zones.

Olivine is fresh, but altered to iddingsite with clay rims and cleavages in the nonoxidized zones. In oxidized zones the olivine is completely altered to clays and, in some cases, iddingsite.

Clinopyroxene is commonly as fresh as in Flow Units 1 and 2.

Glass is generally altered to clay minerals and sometimes to carbonate, although some unaltered glass is present in the freshest parts of the flow (thin section from Sample 432A-3-2, 106-108 cm).

The filling of vesicles and fractures is much the same as in Flow Units 1 and 2.

\section{CHEMISTRY OF VOLCANIC ROCKS (HOLE 432A)}

Six samples from Hole 432A were subjected to chemical analysis. Five of the analyzed samples were from volcanic flows, and the sixth was a large hawaiite cobble from the conglomerate overlying Flow Unit 1 . The five flow samples include one from Flow Unit 1, one from Flow Unit 2, and three from Flow Unit 3. The analyses are given in Table 4. Figure 11 is a plot of total alkalis or silica.

The sample from the conglomerate (Sample 1-1, $35-38 \mathrm{~cm}$ ) is similar to Hawaiian hawaiite, although $\mathrm{Al}_{2} \mathrm{O}_{3}$ content is very high, and both total iron as $\mathrm{Fe}_{2} \mathrm{O}_{3}$ and the $\mathrm{MnO}$ content are low compared with the average Hawaiian hawaiite. Chemically, this sample appears to be transitional between a hawaiite and a mugearite. Ratios of incompatible trace elements such as $\mathrm{P} / \mathrm{Sr}$, $\mathrm{Sr} / \mathrm{K} \mathrm{Zr} / \mathrm{K}, \mathrm{Sr} / \mathrm{Z}$ are different than those of the hawaiite flows cored at Hole 430A (see Table 5).

Flow Units 1 and 2 are chemically alike and similar to average Hawaiian feldspar-phyric basalt of the alkalic suite. Again, the ratios of incompatible trace elements are distinct from the hawaiite clast in the overlying conglomerate and from the hawaiites recovered at Hole 430A.

Flow Unit 3 shows evidence of flow differentiation. The three analyses are similar, although the analysis of Sample 4-4, 84-86 cm yields distinctly higher values for $\mathrm{TiO}_{2}, \mathrm{Al}_{2} \mathrm{O}_{3}, \mathrm{Fe}_{2} \mathrm{O}_{3}, \mathrm{MnO}, \mathrm{K}_{2} \mathrm{O}$, and $\mathrm{P}_{2} \mathrm{O}_{5}$, and lower values for $\mathrm{MgO}, \mathrm{CaO}$, and $\mathrm{Sr}$, compared with either Sample 3-2, 106-108 cm, located above, or Sample 5-1, $128-130 \mathrm{~cm}$, below. Chemically, this flow appears to be 
TABLE 4

Chemical Analyses of Volcanic Rocks from Site 432

\begin{tabular}{|c|c|c|c|c|c|c|}
\hline Core/Section/Piece No. & $1-1, \# 3$ & $2-1, \# 8 B$ & $2-2, \# 11 \mathrm{E}$ & $3-2$ & 4-4, \#6B & $5-1, \# 3 B$ \\
\hline Interval $(\mathrm{cm})$ & $35-38$ & $83-85$ & $100-102$ & $106-108$ & $84-86$ & $128-130$ \\
\hline Rock Type & Hawaiite & Alkali basalt & Alkali basalt & Alkali basalt & Alkali basalt & Alkali basalt \\
\hline Lithologic Unit & $\begin{array}{c}\text { Conglomerate } \\
\text { clast }\end{array}$ & Flow 1 & Flow 2 & Flow 3 & Flow 3 & Flow 3 \\
\hline $\begin{array}{l}\text { Major-Element Oxides (wt. \%) } \\
\mathrm{SiO}_{2} \\
\mathrm{TiO}_{2} \\
\mathrm{Al}_{2} \mathrm{O}_{3} \\
\mathrm{Fe}_{2} \mathrm{O}_{3} \text { (Total) } \\
\mathrm{MnO} \\
\mathrm{MgO} \\
\mathrm{CaO} \\
\mathrm{Na}_{2} \mathrm{O} \\
\mathrm{K}_{2} \mathrm{O} \\
\mathrm{P}_{2} \mathrm{O}_{5}\end{array}$ & $\begin{array}{r}48.35 \\
2.84 \\
20.38 \\
10.95 \\
0.07 \\
2.13 \\
7.39 \\
4.70 \\
1.64 \\
1.12\end{array}$ & $\begin{array}{r}46.75 \\
2.65 \\
16.35 \\
13.19 \\
0.16 \\
6.21 \\
10.19 \\
3.10 \\
0.95 \\
0.52\end{array}$ & $\begin{array}{r}47.49 \\
2.51 \\
18.38 \\
12.78 \\
0.12 \\
3.10 \\
9.97 \\
3.40 \\
1.28 \\
0.58\end{array}$ & $\begin{array}{r}46.64 \\
3.01 \\
15.54 \\
14.58 \\
0.19 \\
5.79 \\
8.36 \\
3.50 \\
1.19 \\
0.49\end{array}$ & $\begin{array}{r}47.91 \\
3.38 \\
17.40 \\
15.58 \\
0.27 \\
3.94 \\
5.87 \\
3.30 \\
1.41 \\
0.54\end{array}$ & $\begin{array}{r}47.69 \\
3.01 \\
15.72 \\
14.47 \\
0.17 \\
5.52 \\
8.30 \\
3.30 \\
1.09 \\
0.48\end{array}$ \\
\hline Total & 99.59 & 100.08 & 79.62 & 99.29 & 99.59 & 99.75 \\
\hline Loss On Ignition (wt. \%) & 7.15 & 4.14 & 4.62 & 1.38 & 7.79 & 2.75 \\
\hline $\left.\begin{array}{l|l}\mathrm{H}_{2} \mathrm{O}^{+} \\
\mathrm{CO}_{2}\end{array}\right\} \begin{array}{l}\text { wt. \% Composition } \\
\text { after baking } \\
\text { off } \mathrm{H}_{2} \mathrm{O}\end{array}$ & $\begin{array}{l}2.66 \\
0.46\end{array}$ & $\begin{array}{l}1.97 \\
0.29\end{array}$ & $\begin{array}{l}1.63 \\
0.31\end{array}$ & $\begin{array}{l}2.62 \\
0.48\end{array}$ & $\begin{array}{l}3.15 \\
0.07\end{array}$ & $\begin{array}{l}1.85 \\
0.10\end{array}$ \\
\hline $\mathrm{Mg} /(\mathrm{Mg}+\mathrm{Fe})$ & 0.27 & 0.48 & 0.32 & 0.44 & 0.33 & 0.43 \\
\hline $\begin{array}{l}\text { Trace Elements (ppm) } \\
\mathrm{Ni} \\
\mathrm{Sr} \\
\mathrm{Zr}\end{array}$ & $\begin{array}{r}19 \\
983 \\
281\end{array}$ & $\begin{array}{r}78 \\
612 \\
168\end{array}$ & $\begin{array}{r}67 \\
726 \\
173\end{array}$ & $\begin{array}{r}50 \\
533 \\
201\end{array}$ & $\begin{array}{r}57 \\
418 \\
209\end{array}$ & $\begin{array}{r}52 \\
500 \\
189\end{array}$ \\
\hline
\end{tabular}

transitional between alkalic basalt and hawaiite of the alkalic suite.

None of the recovered basalt is tholeiitic.

\section{PALEOMAGNETISM (HOLE 432A)}

\section{Introduction}

Hole 432A was drilled on top of Nintoku Seamount at about $41^{\circ} 20^{\prime} \mathrm{N}, 170^{\circ} 23^{\prime} \mathrm{E}$. Five cores were recovered between sub-bottom depths of 36 and 74 meters. Paleomagnetism was studied in samples from Cores 2 through 5. In Core 2, basalt Flow Units 1 and 2 are overlain by a coarse sandstone layer; Cores 3, 4, and 5 consist entirely of a single flow, Flow Unit 3.

Two sandstone samples and 18 basaltic samples were studied. Equipment and experimental procedures are given in detail in the site chapter for Site 430 (Hole 430A) (this volume).

\section{Experimental Results}

Results of experiments on individual samples are summarized in Table 6. In this table, $\mathrm{J}_{\mathrm{NRM}}$ is the intensity of NRM, MDF the mean demagnetizing field, and $\mathrm{Q}_{n}^{\prime}$ the ratio $\mathrm{J}_{\mathrm{NRM}} / \chi$, where $\chi$ is the initial susceptibility.

Sandstone samples show typical results for rocks containing both soft and relatively hard remanences. The intensity drops sharply to about 30 per cent of the original NRM by demagnetization at 150 Oe, decays more slowly between 150 and $300 \mathrm{Oe}$, and changes somewhat irregularly after $400 \mathrm{Oe}$. We can interpret this to mean that the relatively stable remanence has coercivities between 150 and $400 \mathrm{Oe}$, that the behavior of re-

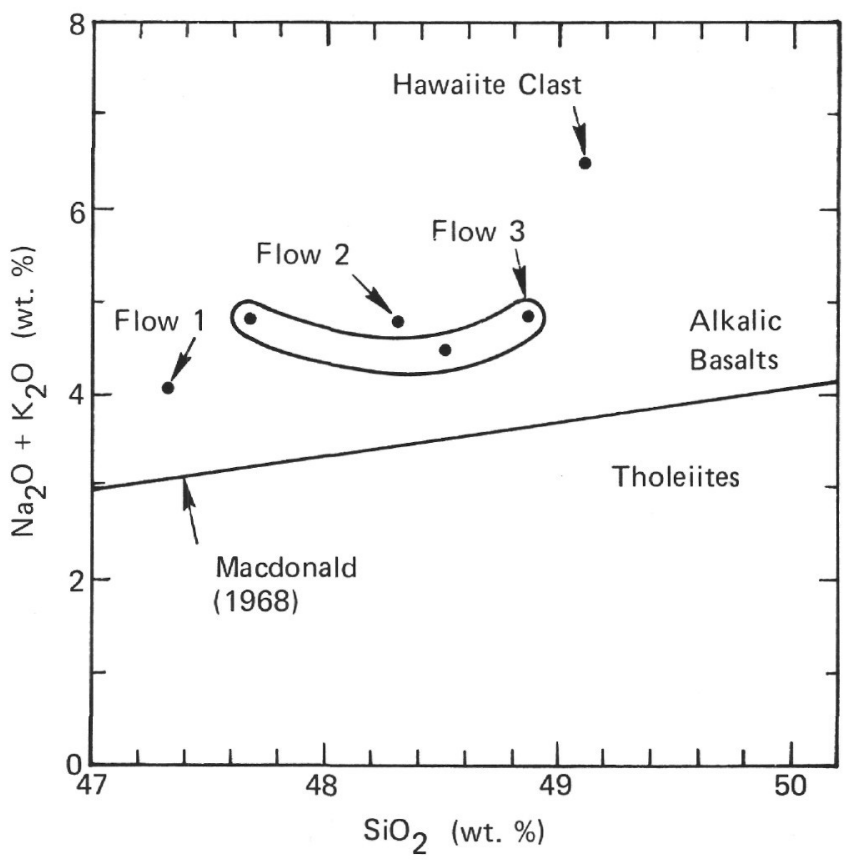

Figure 11. Total alkalis or silica for volcanic rocks from Site 432 .

manence is obscured by soft components in the lower demagnetizing fields, and that it is again complicated after 400 Oe because of the adverse effect in the AF demagnetization process. Although the range of fluctuation is rather wide, even in demagnetizing fields between 150 and $300 \mathrm{Oe}$, we may conclude that the rema- 
TABLE 5

Incompatible-Trace-Element Ratios

\begin{tabular}{lcccccc}
\hline Hole & $430 \mathrm{~A}$ & $430 \mathrm{~A}$ & $432 \mathrm{~A}$ & $432 \mathrm{~A}$ & $432 \mathrm{~A}$ & $432 \mathrm{~A}$ \\
\hline Lithologic & Avg & & & & & \\
Flow & Flow & & $\begin{array}{c}\text { Flow } \\
\text { Unit/Rock }\end{array}$ & $\begin{array}{c}\text { Enits } \\
\text { Unit }\end{array}$ & $\begin{array}{c}\text { Unit } \\
\text { Unit }\end{array}$ & $\begin{array}{c}\text { Flow } \\
\text { Unit }\end{array}$ \\
Type & $1-4$ & 5 & Hawaiite & 1 & 2 & 3 \\
\hline $\mathrm{K} / \mathrm{Sr}$ & 22 & 7 & 14 & 13 & 15 & 21 \\
$\mathrm{~K} / \mathrm{Zr}$ & 31 & 18 & 48 & 47 & 61 & 52 \\
$\mathrm{~K} / \mathrm{P}$ & 2.5 & 2.1 & 2.8 & 3.5 & 4.2 & 4.7 \\
$\mathrm{P} / \mathrm{Sr}$ & 8.6 & 3.4 & 5.0 & 3.7 & 3.5 & 4.5 \\
$\mathrm{P} / \mathrm{Zr}$ & 12.2 & 8.5 & 17.4 & 13.5 & 14.6 & 11.1 \\
$\mathrm{Sr} / \mathrm{Zr}$ & 1.4 & 2.5 & 3.5 & 3.6 & 4.2 & 2.5 \\
\hline
\end{tabular}

nence in this part is dominated by the relatively hard component of magnetization, and is therefore a good measure of the true field direction when the rock was formed.

The behavior of basalt samples in AF demagnetization was much better than that of sandstones. The intensities diminish very smoothly, and the directions were mostly stable between 100 and $700 \mathrm{Oe}$. The inclination of the stable component in Table 6 was taken at $400 \mathrm{Oe}$ for Flow Unit 1, at 300 Oe for Flow Unit 2, and at 200 Oe for Flow Unit 3. Selection of a particular demagnetizing field was based on minimum dispersion in inclination and on smooth and small changes in relative declination, typical of stable remanences. Three samples (2-2, 66-68 cm; 3-1, 109-111 cm; 3-2, 106-108 cm) showed an increase in the magnitude of remanence at low demagnetizing fields. These indicate the presence of a VRM component acquired in the normal polarity field. Secondary soft components, including VRM, if present, were almost completely demagnetized at $150 \mathrm{Oe}$, and the directions of magnetization remained nearly constant at higher demagnetizing fields, except for a few samples which showed irregular changes. It is quite certain that these remanences indicate field directions when the rocks formed.

Figure 12 is a summary of paleomagnetism in Hole 432A. Apparently, inclinations for Flow Units 1 and 2 are very similar, but that for Flow Unit $\mathbf{3}$ is markedly different, and that for the overlying coarse sandstone may also be different from those of Flow Units 1 and 2 .

\section{Discussion on the Derivation of Paleolatitude}

General problems involved in estimating paleolatitude from paleomagnetic data have already been given in the summary for Hole 430A (Site 430 Chapter, this volume). Here we shall briefly discuss the specific problems encountered and anticipated in sampling basalt cores from the Emperor Seamount chain. Three different problems appear to exist: dispersion of directions within a flow unit, secular variation, and distribution of flow units in time. Although low-temperature oxidation is one of the most serious problems in ordinary suboceanic basalts, with possible consequences of destruction of the primary component and creation of secondary CRM, the rocks from both Ōjin and Nintoku seamounts appear to be free from this effect. It is perhaps because these flows erupted subaerially that they differ markedly from the ordinary ocean-ridge basalts which underwent sub-oceanic eruption and subsequent lowtemperature oxidation of titanomagnetites.

The first problem is dispersion of directions within a flow unit. At the Ōjin Seamount site, inclination differed as much as $13^{\circ}$ in four samples from a single flow unit (Hole 430A, Flow Unit 2). As indicated in the discussion of Hole 430A (Site 430 Chapter, this volume), sampling or experimental procedures cannot produce an error of more than a few degrees in this angle. Moreover, individual samples showed a predominance of stable component in their NRM. If such large dispersion within a flow is a constant feature of these basalts, the number of samples per flow unit should be greatly increased to reduce the dispersion and to obtain a field direction with a reasonable margin of error. In the case of Flow 2 at Hole 430A, the standard deviation about the mean inclination obtained from four samples was $5.4^{\circ}$, indicating that the mean inclination can be different from the true field direction by $10^{\circ}$ at the 95 per cent confidence level. At the present site (Hole 432A), 10 samples covering three cores and more than 12 meters in the recovered rock were collected from a thick flow unit (Flow Unit 3). Although some samples contained a considerable contribution of soft secondary components, the inclinations converged to a narrow range near $28^{\circ}$ under $\mathrm{AF}$ demagnetization. Comparing this with other results from Holes $430 \mathrm{~A}$ and $432 \mathrm{~A}$, we can conclude that in the case of Hole 430A, Flow Unit 3 may be exceptional, and that a reasonable estimate of inclination (with standard deviations of about $3^{\circ}$ or less) can be obtained from four or five samples.

The second problem concerns the dispersion between flows. In Hole 432A, the direction of inclination changes abruptly at flow unit boundary $2 / 3$ by about $40^{\circ}$. Although we did not seriously consider Flow Unit 5 at Hole $430 \mathrm{~A}$, because of the paucity of samples, the change in (absolute values of) inclination at boundary $4 / 5$ was similarly large. If these are adequate samplings of typical paleosecular variation (PSV) recorded in these seamounts, and if they do not represent peculiar direction changes in the times of polarity transition, either reversal or excursion, then we should expect a wide range for the PSV and therefore considerable difficulty in averaging that out.

Considerable work has been done on paleomagnetism in the Hawaiian Islands, and it seems to have established that the secular variation is much smaller in the central part of the Pacific Ocean than in other regions of the same latitude zone (Cox and Doell, 1964). This "Pacific quietness" has been a constant feature in the vicinity of Hawaii for at least the last $5 \mathrm{~m} . \mathrm{y}$. (Doell and Cox, 1972). The change in the PSV recorded in the Hawaiian-Emperor chain may prove a provocative subject in studies of geomagnetic-tectonic connection and long-term trends in the geomagnetic field.

The third problem concerns the spacing of lavas in time. At Ōjin Seamount, we drilled five flow units, but the upper four had essentially identical inclinations. The same situation was observed at Nintoku Seamount for Flow Units 1 and 2. This suggests that some of the flow 
TABLE 6

Paleomagnetism, Hole 432A

\begin{tabular}{|c|c|c|c|c|c|c|c|c|c|}
\hline $\begin{array}{c}\text { Sample } \\
\text { (Interval in cm) }\end{array}$ & Unit & $\begin{array}{l}\text { Sub-bottom } \\
\text { Depth } \\
\text { (m) }\end{array}$ & $\begin{array}{c}{ }^{\mathrm{J}} \mathrm{NRM} \\
\left(\times 10^{-5} \mathrm{emu} / \mathrm{cm}^{3}\right)\end{array}$ & $\begin{array}{c}\text { Inclination } \\
\text { of NRM } \\
\left(^{\circ}\right)\end{array}$ & $\begin{array}{c}\text { Stable } \\
\text { Inclination } \\
\left(^{\circ}\right)\end{array}$ & $\begin{array}{l}\text { (AF) } \\
(\mathrm{Oe})\end{array}$ & $\begin{array}{r}\mathrm{MDF} \\
(\mathrm{Oe})\end{array}$ & $\begin{array}{c}\text { Suscept. } \\
\times \\
\left(\times 10^{-5}\right)\end{array}$ & $\mathrm{Q}_{\mathrm{n}}(\mathrm{Oe})^{\mathrm{b}}$ \\
\hline $2-1,28-30$ & SS & 41.75 & 0.46 & -62.3 & -48.7 & 300 & 119 & 2.07 & 0.52 \\
\hline $2-1,33-35$ & SS & $41 . .81$ & 0.35 & -54.8 & -40.1 & $\mathrm{THD}^{\mathrm{a}}$ & & 1.85 & 0.44 \\
\hline $2-1,43-45$ & SS & 41.88 & 0.39 & -52.5 & -44.7 & 300 & 124 & 1.40 & 0.66 \\
\hline $2-1,74-76$ & 1 & 42.13 & 7.75 & -62.5 & -65.0 & THDa & & 1.98 & 9.18 \\
\hline $2-1,83-85$ & 1 & 42.21 & 6.91 & -59.9 & -64.8 & 400 & 363 & 1.90 & 8.51 \\
\hline $2-1,107-109$ & 1 & 42.46 & 5.15 & -63.7 & -63.9 & THDa & & 2.30 & 5.26 \\
\hline $2-1,115-117$ & 1 & 42.52 & 4.59 & -60.9 & -64.7 & 400 & 329 & 1.74 & 6.18 \\
\hline $2-1,133-135$ & 1 & 42.66 & 6.69 & -66.0 & -67.6 & 400 & 340 & 1.57 & 10.01 \\
\hline $2-2,41-43$ & 2 & 43.09 & 9.50 & -64.4 & -66.9 & 300 & 392 & 2.09 & 10.67 \\
\hline $2-2,66-68$ & 2 & 43.27 & 12.30 & -66.3 & -67.3 & 300 & 410 & 2.09 & 13.83 \\
\hline $2-2,72-74$ & 2 & 43.34 & 8.82 & -68.7 & -66.0 & THD $^{\mathrm{a}}$ & & 2.25 & 9.21 \\
\hline $2-2,100-102$ & 2 & 43.61 & 10.70 & -67.0 & -67.9 & 300 & 372 & 1.91 & 13.14 \\
\hline $2-3,2-4$ & 2 & 44.02 & 3.73 & -61.3 & -63.7 & 300 & 385 & 1.04 & 8.42 \\
\hline $2-3,12-14$ & 2 & 44.13 & 2.82 & -62.6 & -63.1 & $\mathrm{THD}^{\mathrm{a}}$ & & 1.20 & 5.50 \\
\hline $2-3,21-23$ & 2 & 44.22 & 2.08 & -62.8 & -65.1 & THDa & & 1.21 & 4.04 \\
\hline $2-3,31-33$ & 2 & 44.31 & 3.54 & -69.4 & -70.7 & 300 & 277 & 1.03 & 8.05 \\
\hline $3-1,109-111$ & 3 & 55.91 & 3.46 & -46.5 & -26.8 & 200 & 157 & 4.09 & 1.99 \\
\hline $3-2,67-69$ & 3 & 56.77 & 2.57 & -24.7 & -24.3 & THDa & & 6.49 & $0.93^{c}$ \\
\hline $3-2,106-108$ & 3 & 57.07 & 3.63 & -58.6 & -26.9 & 200 & 176 & 5.37 & 1.59 \\
\hline $3-3,92-94$ & 3 & 58.18 & 9.34 & -26.3 & -27.2 & 200 & 158 & 3.19 & 6.87 \\
\hline $4-1,64-66$ & 3 & 65.08 & 7.22 & -31.9 & -30.0 & THD ${ }^{a}$ & & 3.65 & 4.65 \\
\hline $4-1,69-71$ & 3 & 65.12 & 8.90 & -30.2 & -30.6 & 200 & 335 & 2.96 & 7.05 \\
\hline $4-1,73-75$ & 3 & 65.17 & 7.28 & -29.6 & -29.0 & $\mathrm{THD}^{\mathrm{a}}$ & & 3.20 & 5.35 \\
\hline $4-1,120-122$ & 3 & 65.59 & 3.87 & -28.3 & -28.2 & THD $^{\mathrm{a}}$ & & 3.03 & 3.00 \\
\hline $4-2,41-43$ & 3 & 66.23 & 9.35 & -28.4 & -27.3 & 200 & 258 & 2.46 & 8.92 \\
\hline $4-2,80-82$ & 3 & 66.60 & 8.36 & -27.4 & -29.3 & $\mathrm{THD}^{\mathrm{a}}$ & & 2.80 & 7.02 \\
\hline $4-3,51-53$ & 3 & 67.69 & 6.05 & -30.3 & -29.7 & 200 & 123 & 1.89 & 7.49 \\
\hline $4-4,84-86$ & 3 & 69.15 & 4.82 & -31.6 & -30.0 & 200 & 183 & 1.66 & 6.82 \\
\hline $4-5,119-121$ & 3 & 70.81 & 4.72 & -29.9 & -25.7 & 200 & 134 & 1.46 & 7.60 \\
\hline $5-1,128-130$ & 3 & 72.23 & 5.25 & -32.5 & -29.4 & 200 & 65 & 2.61 & 4.72 \\
\hline $5-2,55-57$ & 3 & 72.89 & 5.34 & -44.3 & -30.1 & 200 & 66 & 2.84 & 4.41 \\
\hline $5-2,69-71$ & 3 & 73.04 & 2.53 & -44.8 & -31.6 & THDa & & 1.88 & $3.16^{\mathrm{c}}$ \\
\hline
\end{tabular}

${ }^{\mathrm{a}} \mathrm{THD}=$ Thermal demagnetization.

${ }^{\mathrm{K} o ̈ n i g s b e r g e r ~ r a t i o ~} \mathrm{Q}_{\mathrm{n}}$ calculated using geomagnetic intensities given in Kono (this volume).

${ }^{c}$ Not used in the calculation of the flow mean inclination.

units erupted in quick succession within a very short period, and may not provide adequate sampling of secular variation. The concentration of volcanic activity in a short period is a commonly observed phenomenon in Hawaiian-type volcanoes. In fact, Coe et al. (1978) suggest that a possible explanation for the "Pacific quietness" observed by Doell and Cox (1972) may be that the lavas they sampled erupted in quick succession, and that they did not adequately express the whole range of PSV.

\section{Conclusions}

Twenty samples from three basalt flow units and an overlying sandstone layer were studied. The sandstone samples are magnetically less stable than basalt samples, but both retain the original field directions. Unlike Flow Unit 2 at Hole $430 \mathrm{~A}$, the dispersion in inclination is small for every basaltic unit. The inclination changes markedly at flow unit boundary $2 / 3$, and may indicate a large secular variation at the time these rocks formed.

\section{PHYSICAL PROPERTIES}

Velocity and density were measured on samples from Holes 432 and $432 \mathrm{~A}$, using the sonic pulse and the GRAPE apparatus, as described earlier. Results of the measurements are presented in Figures 13 and 14 and in Tables 7 and 8 .

In the top 5 meters at this site (Hole 432), the fine mud and sand mixture has a velocity of about $1.8 \mathrm{~km}$ and a density of about $1.5 \mathrm{~g} / \mathrm{cm}^{3}$. After the breakoff in Hole 432, Hole 432A was washed down to a depth of about 39 meters. Four pieces of core were recovered in Core 1: a gray sandstone $(\mathrm{V}=2.7 \mathrm{~km} / \mathrm{s})$, a large beach pebble $(\mathrm{V}=3.9 \mathrm{~km} / \mathrm{s})$, and two pieces of cemented conglomerate $(\mathrm{V}=4.4 \mathrm{~km} / \mathrm{s})$. Densities of these samples were not measured, primarily because their shapes were not optimum for the GRAPE apparatus. The top $60 \mathrm{~cm}$ (or so) of Core 2 consists of gray sandstone (interval $41.5 \mathrm{~m}$ to about $42.1 \mathrm{~m}$ sub-bottom). The velocity and density of this unit are roughly $3.7 \mathrm{~km} / \mathrm{s}$ 


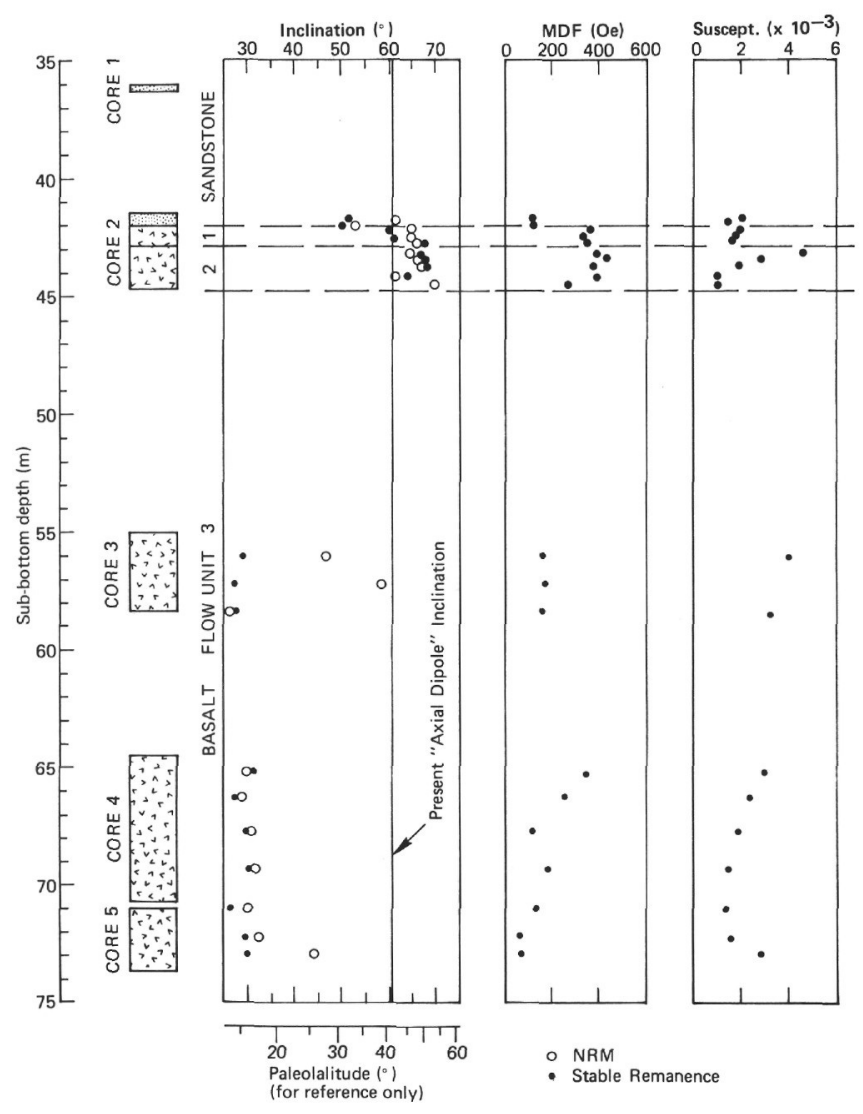

Figure 12. Inclinations of NRM and stable remanence, mean demagnetizing field (MDF), and initial susceptibility of samples from Hole $432 \mathrm{~A}$ as a function of sub-bottom depth.

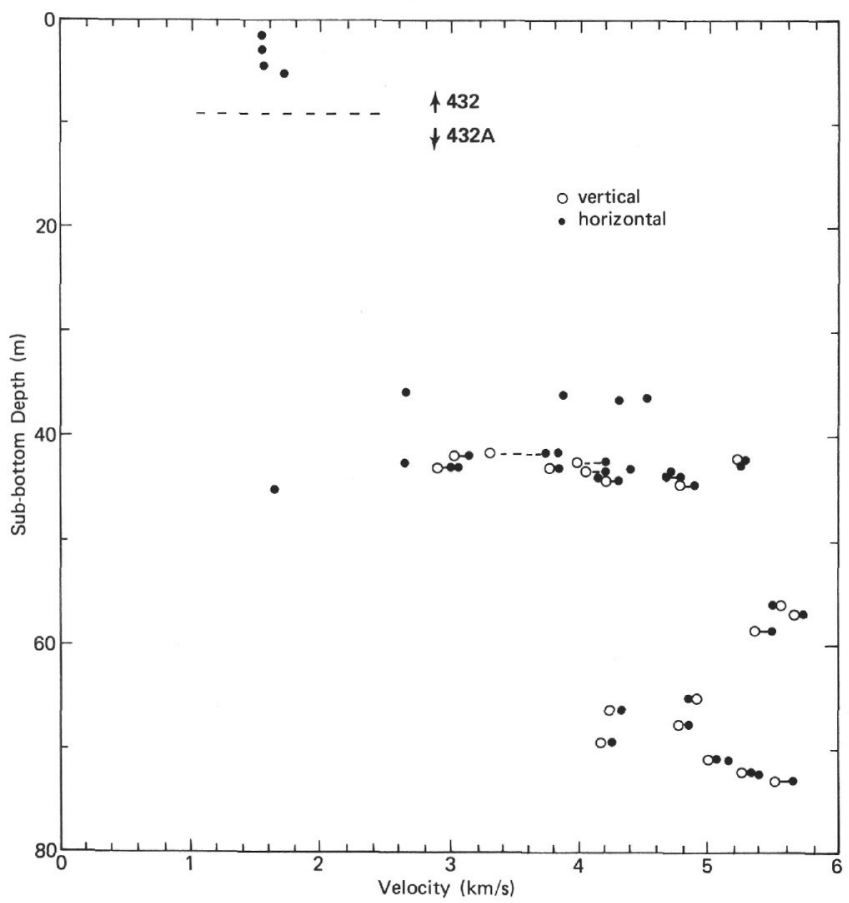

Figure 13. Sonic velocity versus depth for Site 432.

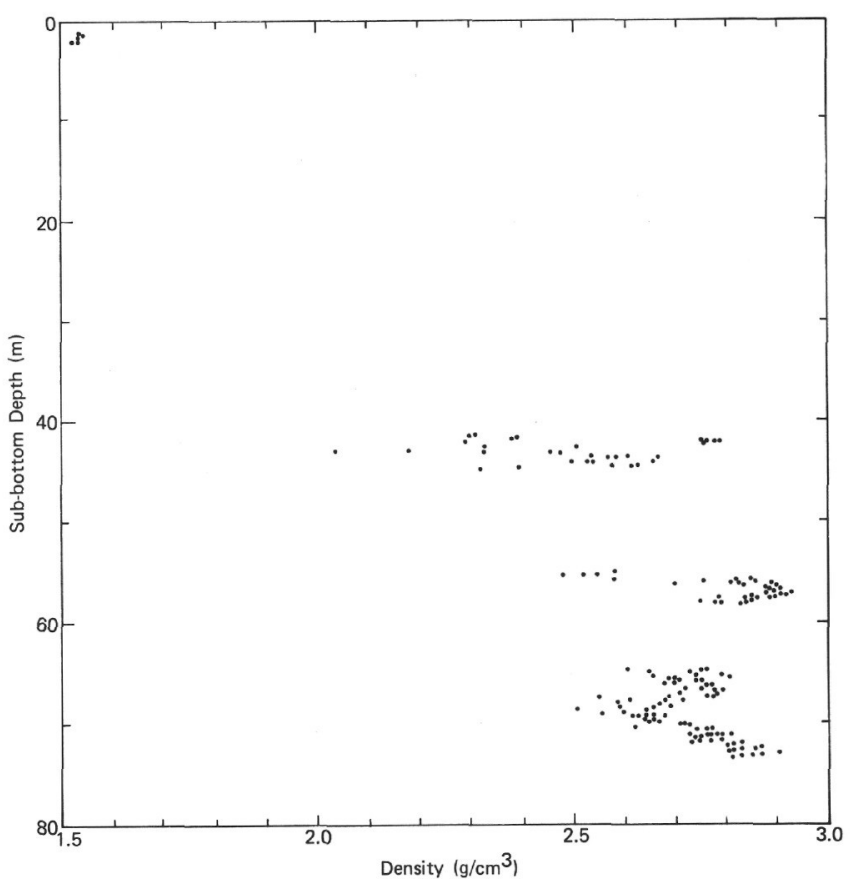

Figure 14. Density versus depth for Site 432.

and $2.3 \mathrm{~g} / \mathrm{cm}^{3}$, respectively. Velocity anisotropy occurs here: the vertical velocity is 5 to 10 per cent less than the horizontal velocity.

Basalt Flow Unit 1 was identified lithologically in the next $80 \mathrm{~cm}$ or so of this core. The top of the original flow appears to have been eroded; we interpreted the sandstone to be in contact with the interior of this flow. The physical properties agree with the lithologic interpretation: the velocity and density are $5.2 \mathrm{~km} / \mathrm{s}, 2.8$ $\mathrm{g} / \mathrm{cm}^{3}$ (typical of a weathered basalt), respectively, with no gradation down from the top. These quantities decrease, however, in the lower half of this flow unit (where increasing amounts of clay-filled vesicles occur) to a low of $2.7 \mathrm{~km} / \mathrm{s}$ and $2.3 \mathrm{~g} / \mathrm{cm}^{3}$. Velocity anisotropy is very small within this unit, generally within the error of the experimental technique.

Flow Unit 2 was identified lithologically as extending from about $\mathbf{4 2 . 8}$ meters to 45.0 meters sub-bottom. This is a highly weathered basalt, petrologically very similar to Flow Unit 1, with maximum velocities and densities of $4.8 \mathrm{~km} / \mathrm{s}$ and $2.6 \mathrm{~g} / \mathrm{cm}^{3}$, respectively; toward the top and bottom, the values are lower. The velocity anisotropy of this unit is small; in the five samples measured, the vertical velocity is generally 3 per cent less than the horizontal velocity. Below this unit, an interval of red clay $(\mathrm{V}=1.6 \mathrm{~km} / \mathrm{s})$ was recovered. Because incomplete recovery, this low velocity layer could be anywhere from $10 \mathrm{~cm}$ to 10 meters thick.

The top of Flow Unit 3 was recovered at 55 meters depth. The top of the flow is partly oxidized, and the top $80 \mathrm{~cm}$ reflects this in its low density $\left(2.5 \mathrm{~g} / \mathrm{cm}^{3}\right)$. Farther down, the unit grades into a very fresh, finegrained basalt with velocity of $5.7 \mathrm{~km} / \mathrm{s}$ and density of $2.9 \mathrm{~g} / \mathrm{cm}^{3}$. At the bottom of Core 3 , a region containing 
TABLE 7

Velocity Measurements, Site 432

\begin{tabular}{cccc}
\hline & & & Velocity, \\
Sub-bottom & $\begin{array}{c}\text { Core-Section, } \\
\text { Depth (m) }\end{array}$ & $\begin{array}{c}\text { Velocity, } \\
\text { Sample Location }(\mathrm{cm})\end{array}$ & $\begin{array}{c}\text { Vertical } \\
(\mathrm{km})\end{array}$ \\
\hline Hole 432 & & & \\
1.65 & $1-2,15$ & $1.55 \pm 0.06$ & \\
3.18 & $1-3,18$ & $1.55 \pm 0.06$ & \\
4.73 & $1-4,23$ & $1.57 \pm 0.06$ & \\
5.44 & $1-4,94$ & $1.75 \pm 0.07$ & \\
Hole $432 \mathrm{~A}$ & & & \\
36.10 & $1-1,10$ & $2.65 \pm 0.07$ & \\
36.20 & $1-1,20$ & $3.86 \pm 0.15$ & \\
36.35 & $1-1,35$ & $4.55 \pm 0.02$ & \\
36.45 & $1-1,45$ & $4.32 \pm 0.05$ & \\
41.75 & $2-1,25$ & $3.84 \pm 0.02$ & \\
41.79 & $2-1,29$ & $3.75 \pm 0.04$ & $3.31 \pm 0.02$ \\
41.94 & $2-1,44$ & $3.16 \pm 0.09$ & $3.01 \pm 0.03$ \\
42.34 & $2-1,84$ & $5.29 \pm 0.06$ & $5.16 \pm 0.05$ \\
42.39 & $2-1,89$ & $5.23 \pm 0.02$ & \\
42.66 & $2-1,116$ & $4.22 \pm 0.03$ & $3.98 \pm 0.05$ \\
42.80 & $2-1,130$ & $2.65 \pm 0.02$ & \\
42.84 & $2-1,134$ & $3.05 \pm 0.15$ & $2.92 \pm 0.08$ \\
43.08 & $2-2,8$ & $3.05 \pm 0.08$ & \\
43.42 & $2-2,42$ & $3.83 \pm 0.06$ & $3.80 \pm 0.03$ \\
43.52 & $2-2,52$ & $4.43 \pm 0.06$ & \\
43.67 & $2-2,67$ & $4.25 \pm 0.04$ & $4.04 \pm 0.03$ \\
43.87 & $2-2,87$ & $4.76 \pm 0.03$ & \\
44.01 & $2-2,101$ & $4.81 \pm 0.04$ & $4.68 \pm 0.04$ \\
44.45 & $2-2,145$ & $4.17 \pm 0.02$ & \\
44.53 & $2-3,3$ & $4.33 \pm 0.18$ & $4.18 \pm 0.17$ \\
45.02 & $2-3,52$ & $4.90 \pm 0.05$ & $4.78 \pm 0.06$ \\
45.45 & $2-\mathrm{CC}, 25$ & $1.65 \pm 0.02$ & \\
56.10 & $3-1,110$ & $5.32 \pm 0.06$ & $5.36 \pm 0.06$ \\
57.57 & $3-2,107$ & $5.72 \pm 0.03$ & $5.70 \pm 0.03$ \\
58.93 & $3-3,93$ & $5.50 \pm 0.11$ & $5.35 \pm 0.04$ \\
65.15 & $4-1,70$ & $4.91 \pm 0.15$ & $4.92 \pm 0.03$ \\
$66.25 \dagger$ & $4-2,42$ & $4.35 \pm 0.05$ & $4.25 \pm 0.04$ \\
$67.69 \dagger$ & $4-3,52$ & $4.85 \pm 0.04$ & $4.79 \pm 0.02$ \\
$69.32 \dagger$ & $4-4,85$ & $4.28 \pm 0.07$ & $4.17 \pm 0.04$ \\
$70.96 \dagger$ & $4-5,115$ & $5.17 \pm 0.03$ & \\
$71.00 \dagger$ & $4-5,120$ & $5.10 \pm 0.08$ & $5.05 \pm 0.04$ \\
72.29 & $5-1,129$ & $5.33 \pm 0.10$ & $5.31 \pm 0.02$ \\
72.39 & $5-1,139$ & $5.39 \pm 0.04$ & \\
73.06 & $5-2,56$ & $5.65 \pm 0.05$ & $5.50 \pm 0.03$ \\
\hline
\end{tabular}

Note: Sub-bottom depths (indicated by $\dagger$ ) not calculated with simple formula, because the core plus spacers is longer than the total interval drilled.

some clay-filled veins shows lower velocity and density $\left(5.5 \mathrm{~km} / \mathrm{s}, 2.8 \mathrm{~g} / \mathrm{cm}^{3}\right)$. Two zones having oxidation along many small fractures occur at Section 4-1 $(0 \mathrm{~cm})$ and at Section 4-3 $(67 \mathrm{~cm})$. They correlate with lowvelocity and low-density zones. Between these zones, the fresh, medium-grained basalt has a velocity varying from 5.0 to $5.6 \mathrm{~km} / \mathrm{s}$ and a density of about 2.7 to 2.8 $\mathrm{g} / \mathrm{cm}^{3}$. Velocity anisotropy is in the 1 to 2 per cent range.

\section{CORRELATION OF SEISMIC PROFILES WITH DRILLED SEQUENCE}

The seismic stratigraphy of Nintoku Seamount is difficult to define because most of the differing acoustic units apparently lie within the bubble pulse (Figures 4
TABLE 8

GRAPE Density Measurements, Site 432

\begin{tabular}{|c|c|c|}
\hline $\begin{array}{c}\text { Core-Section, } \\
\text { Sample Location }(\mathrm{cm})\end{array}$ & $\begin{array}{l}\text { Sub-bottom } \\
\text { Depth (m) }\end{array}$ & $\begin{array}{l}\text { GRAPE Density } \\
\left(\mathrm{g} / \mathrm{cm}^{3}\right)\end{array}$ \\
\hline \multicolumn{3}{|l|}{ Hole 432} \\
\hline $1-2,10$ & 1.60 & 1.54 \\
\hline $1-2,20$ & 1.70 & 1.54 \\
\hline $1-2,30$ & 1.80 & 1.54 \\
\hline $1-2,40$ & 1.90 & 1.52 \\
\hline \multicolumn{3}{|l|}{ Hole 432A } \\
\hline $2-1,28$ & 41.78 & 2.30 \\
\hline $2-1,35$ & 41.85 & 2.39 \\
\hline $2-1,45$ & 41.95 & 2.31 \\
\hline $2-1,53$ & 42.03 & 2.39 \\
\hline $2-1,62$ & 42.12 & 2.29 \\
\hline $2-1,74$ & 42.24 & 2.75 \\
\hline $2-1,82$ & 42.32 & 2.77 \\
\hline $2-1,90$ & 42.40 & 2.79 \\
\hline $2-1,96$ & 42.46 & 2.78 \\
\hline $2-1,105$ & 42.58 & 2.76 \\
\hline $2-1,119$ & 42.69 & 2.51 \\
\hline $2-1,134$ & 42.84 & $2.29^{\mathrm{a}}$ \\
\hline $2-1,134$ & 42.84 & 2.33 \\
\hline $2-2,10$ & 43.10 & 2.18 \\
\hline $2-2,25$ & 43.25 & 2.03 \\
\hline $2-2,42$ & 43.42 & $2.45^{\mathrm{a}}$ \\
\hline $2-2,44$ & 43.44 & 2.33 \\
\hline $2-2,55$ & 43.55 & 2.46 \\
\hline $2-2,70$ & 43.70 & 2.48 \\
\hline $2-2,79$ & 43.79 & 2.59 \\
\hline $2-2,88$ & 43.88 & 2.61 \\
\hline $2-2,92$ & 43.92 & 2.54 \\
\hline $2-2,101$ & 44.01 & $2.71^{\mathrm{a}}$ \\
\hline $2-2,102$ & 44.02 & 2.67 \\
\hline $2-2,110$ & 44.10 & 2.57 \\
\hline $2-2,147$ & 44.47 & 2.66 \\
\hline $2-3,3$ & 44.53 & $2.69^{a}$ \\
\hline $2-3,6$ & 44.56 & 2.54 \\
\hline $2-3,12$ & 44.62 & 2.50 \\
\hline $2-3,20$ & 44.70 & 2.53 \\
\hline $2-3,28$ & 44.78 & 2.62 \\
\hline $2-3,36$ & 44.86 & 2.62 \\
\hline $2-3,40$ & 44.90 & 2.63 \\
\hline $2-3,46$ & 44.96 & 2.58 \\
\hline $2-3,52$ & 45.02 & $2.73^{\mathrm{a}}$ \\
\hline $2-3,53$ & 45.03 & 2.40 \\
\hline $2-3,64$ & 45.14 & 2.32 \\
\hline $3-1,32$ & 55.32 & 2.55 \\
\hline $3-1,42$ & 55.42 & 2.48 \\
\hline $3-1,50$ & 55.50 & 2.53 \\
\hline $3-1,84$ & 55.84 & 2.58 \\
\hline $3-1,106$ & 56.06 & 2.85 \\
\hline $3-1,109$ & 56.09 & 2.86 \\
\hline $3-1,110$ & 56.10 & $2.86^{\mathrm{a}}$ \\
\hline $3-1,117$ & 56.17 & 2.82 \\
\hline $3-1,120$ & 56.20 & 2.89 \\
\hline $3-1,127$ & 56.27 & 2.76 \\
\hline $3-1,139$ & 56.39 & 2.81 \\
\hline $3-2,8$ & 56.58 & 2.70 \\
\hline $3-2,16$ & 56.66 & 2.83 \\
\hline $3-2,26$ & 56.76 & 2.83 \\
\hline $3-2,35$ & 56.85 & 2.90 \\
\hline $3-2,46$ & 56.96 & 2.88 \\
\hline $3-2,60$ & 57.10 & 2.91 \\
\hline $3-2,71$ & 57.21 & 2.89 \\
\hline $3-2,80$ & 57.30 & 2.90 \\
\hline $3-2,97$ & 57.47 & 2.88 \\
\hline $3-2,106$ & 57.56 & 2.93 \\
\hline $3-2,107$ & 57.57 & $2.93^{\mathrm{a}}$ \\
\hline
\end{tabular}


TABLE 8 - Continued

\begin{tabular}{|c|c|c|}
\hline $\begin{array}{c}\text { Core-Section. } \\
\text { Sample Location }(\mathrm{cm})\end{array}$ & $\begin{array}{l}\text { Sub-bottom } \\
\text { Depth }(\mathrm{m})\end{array}$ & $\begin{array}{l}\text { GRAPE Density } \\
\qquad\left(\mathrm{g} / \mathrm{cm}^{3}\right)\end{array}$ \\
\hline \multicolumn{3}{|l|}{ Hole 432A } \\
\hline $3-2,113$ & 57.63 & 2.92 \\
\hline $3-2,122$ & 57.72 & 2.90 \\
\hline $3-2,131$ & 57.81 & 2.90 \\
\hline $3-2,142$ & 57.92 & 2.89 \\
\hline $3-3,6$ & 58.06 & 2.79 \\
\hline $3-3,17$ & 58.17 & 2.86 \\
\hline $3-3,28$ & 58.28 & 2.85 \\
\hline $3-3,36$ & 58.36 & 2.85 \\
\hline $3-3,46$ & 58.46 & 2.84 \\
\hline $3-3,56$ & 58.56 & 2.85 \\
\hline $3-3,68$ & 58.68 & 2.75 \\
\hline $3-3,72$ & 58.72 & 2.84 \\
\hline $3-3,82$ & 58.82 & 2.78 \\
\hline $3-3,86$ & 58.86 & 2.83 \\
\hline $3-3,93$ & 58.93 & 2.84 \\
\hline $3-3,95$ & 58.95 & 2.79 \\
\hline $4-1,13$ & $64.61 \dagger$ & 2.76 \\
\hline $4-1,18$ & $64.66 \dagger$ & 2.76 \\
\hline $4-1,31$ & $64.78^{\dagger}$ & 2.75 \\
\hline $4-1,42$ & $64.87 \dagger$ & 2.65 \\
\hline $4-1,47$ & $64.92 \dagger$ & 2.61 \\
\hline $4-1,60$ & $65.05 \dagger$ & 2.65 \\
\hline $4-1,65$ & $65.10^{\dagger}$ & 2.73 \\
\hline $4-1,70$ & $65.15 \dagger$ & $2.79^{\mathrm{a}}$ \\
\hline $4-1,74$ & $65.19 \dagger$ & 2.74 \\
\hline $4-1,82$ & $65.27 \dagger$ & 2.79 \\
\hline $4-1,104$ & $65.47 \dagger$ & 2.81 \\
\hline $4-1,114$ & $65.57 \dagger$ & 2.74 \\
\hline $4-1,125$ & $65.68 \dagger$ & 2.69 \\
\hline $4-1,130$ & $65.73 \dagger$ & 2.69 \\
\hline $4-1,135$ & $65.78^{\dagger}$ & 2.71 \\
\hline $4-1,140$ & $65.83 \dagger$ & 2.75 \\
\hline $4-2,10$ & $65.94 \dagger$ & 2.74 \\
\hline $4-2,29$ & $66.12 \dagger$ & 2.70 \\
\hline $4-2,39$ & $66.22 \dagger$ & 2.68 \\
\hline $4-2,42$ & $66.25 \dagger$ & $2.65^{\mathrm{a}}$ \\
\hline $4-2,48$ & $66.31 \dagger$ & 2.75 \\
\hline $4-2,56$ & $66.39 \dagger$ & 2.77 \\
\hline $4-2,65$ & $66.48 \dagger$ & 2.77 \\
\hline $4-2,81$ & $66.62 \dagger$ & 2.72 \\
\hline $4-2,89$ & $66.70^{\dagger}$ & 2.75 \\
\hline $4-2,96$ & $66.77 \dagger$ & 2.78 \\
\hline $4-2,108$ & $66.89 \dagger$ & 2.79 \\
\hline $4-2,118$ & $66.99 \dagger$ & 2.71 \\
\hline $4-2,127$ & $67.08 \dagger$ & 2.78 \\
\hline $4-3,19$ & $67.37 \dagger$ & 2.55 \\
\hline $4-3,31$ & $67.48 \dagger$ & 2.69 \\
\hline $4-3,36$ & $67.53 \dagger$ & 2.76 \\
\hline $4-3,45$ & $67.62 \dagger$ & 2.77 \\
\hline $4-3,52$ & $67.69 \dagger$ & $2.72^{\mathrm{a}}$ \\
\hline $4-3,55$ & $67.72 \dagger$ & 2.72 \\
\hline $4-3,60$ & $67.77 \dagger$ & 2.68 \\
\hline $4-3,78$ & $67.93 \dagger$ & 2.61 \\
\hline $4-3,113$ & $68.23 \dagger$ & 2.59 \\
\hline $4-3,128$ & $68.36 \dagger$ & 2.67 \\
\hline $4-3,141$ & $68.48^{\dagger}$ & 2.66 \\
\hline $4-4,9$ & $68.61 \dagger$ & 2.69 \\
\hline $4-4,18$ & $68.70 \dagger$ & 2.64 \\
\hline $4-4,24$ & $68.76 \dagger$ & 2.51 \\
\hline $4-4,43$ & $68.93 \dagger$ & 2.60 \\
\hline $4-4,57$ & $69.05 \dagger$ & 2.56 \\
\hline $4-4,70$ & $69.17 \dagger$ & 2.64 \\
\hline $4-4,80$ & $69.27 \dagger$ & 2.62 \\
\hline $4-4,85$ & $69.32 \dagger$ & 2.62 \\
\hline $4-4,85$ & $69.32 \dagger$ & $2.56^{\mathrm{a}}$ \\
\hline $4-4,93$ & $69.40 \dagger$ & 2.66 \\
\hline
\end{tabular}

TABLE 8 - Continued

\begin{tabular}{ccc}
\hline $\begin{array}{c}\text { Core-Section, } \\
\text { Sample Location (cm) }\end{array}$ & $\begin{array}{c}\text { Sub-bottom } \\
\text { Depth }(\mathrm{m})\end{array}$ & $\begin{array}{c}\text { GRAPE Density } \\
\left(\mathrm{g} / \mathrm{cm}^{3}\right)\end{array}$ \\
\hline Hole 432A & & \\
$4-4,102$ & $69.49 \dagger$ & 2.68 \\
$4-4,119$ & $69.64 \dagger$ & 2.64 \\
$4-4,128$ & $69.73 \dagger$ & 2.66 \\
$4-4,137$ & $69.82 \dagger$ & 2.66 \\
$4-4,141$ & $69.86 \dagger$ & 2.67 \\
$4-5,7$ & $69.95 \dagger$ & 2.65 \\
$4-5,20$ & $70.07 \dagger$ & 2.72 \\
$4-5,32$ & $70.19 \dagger$ & 2.71 \\
$4-5,46$ & $70.32 \dagger$ & 2.72 \\
$4-5,57$ & $70.42 \dagger$ & 2.62 \\
$4-5,71$ & $70.55 \dagger$ & 2.77 \\
$4-5,88$ & $70.71 \dagger$ & 2.74 \\
$4-5,104$ & $70.85 \dagger$ & 2.77 \\
$4-5,117$ & $70.97 \dagger$ & 2.76 \\
$4-5,120$ & $71.00 \dagger$ & $2.72^{\mathrm{a}} \dagger$ \\
$5-1,7$ & 71.07 & 2.77 \\
$5-1,15$ & 71.15 & 2.81 \\
$5-1,20$ & 71.20 & 2.78 \\
$5-1,27$ & 71.27 & 2.77 \\
$5-1,33$ & 71.33 & 2.73 \\
$5-1,41$ & 71.41 & 2.79 \\
$5-1,49$ & 71.49 & 2.76 \\
$5-1,57$ & 71.57 & 2.74 \\
$5-1,62$ & 71.62 & 2.79 \\
$5-1,67$ & 71.67 & 2.77 \\
$5-1,76$ & 71.76 & 2.75 \\
$5-1,81$ & 71.81 & 2.73 \\
$5-1,95$ & 71.95 & 2.68 \\
$5-1,102$ & 72.02 & 2.83 \\
$5-1,114$ & 72.14 & 2.81 \\
$5-1,124$ & 72.24 & 2.80 \\
$5-1,129$ & 72.29 & $2.88^{\mathrm{a}}$ \\
$5-1,141$ & 72.41 & 2.86 \\
$5-2,8$ & 72.58 & 2.87 \\
$5-2,19$ & 72.69 & 2.83 \\
$5-2,42$ & 72.92 & 2.81 \\
$5-2,52$ & 73.02 & 2.80 \\
$5-2,56$ & 73.06 & $2.93^{\mathrm{a}}$ \\
$5-2,63$ & 73.13 & 2.85 \\
$5-2,70$ & 73.20 & 2.87 \\
$5-2,79$ & 73.29 & 73.43 \\
$5-2,93$ & 73.51 & \\
$5-2,101$ & & \\
\hline & & \\
\hline
\end{tabular}

Note: Sub-bottom depths (indicated by $\dagger$ ) not calculated by simple rule, because the core plus spacers is longer the total interval drilled.

${ }^{\mathrm{a}}$ Indicates more accurate two-minute GRAPE count.

and 5). The large amount of acoustic ringing must result from trapping the seismic signal within shallow layers of alternating densities. Locally, distortions of the bubble pulse and the ringing reflectors suggest the stratigraphic position of the basement surface and overlying sediments. Acoustic basement appears as an irregular undulating surface that gradually dips from the center of Nintoku Seamount, where it may crop out, to the outer edge, where it also may crop out on the steep upper flank of the seamount (see Figure 15a and 15b).

The lithologic units recovered in Holes 432 and 432A cannot be accurately correlated with the seismic stratigraphy, because much of this stratigraphy lies within the 


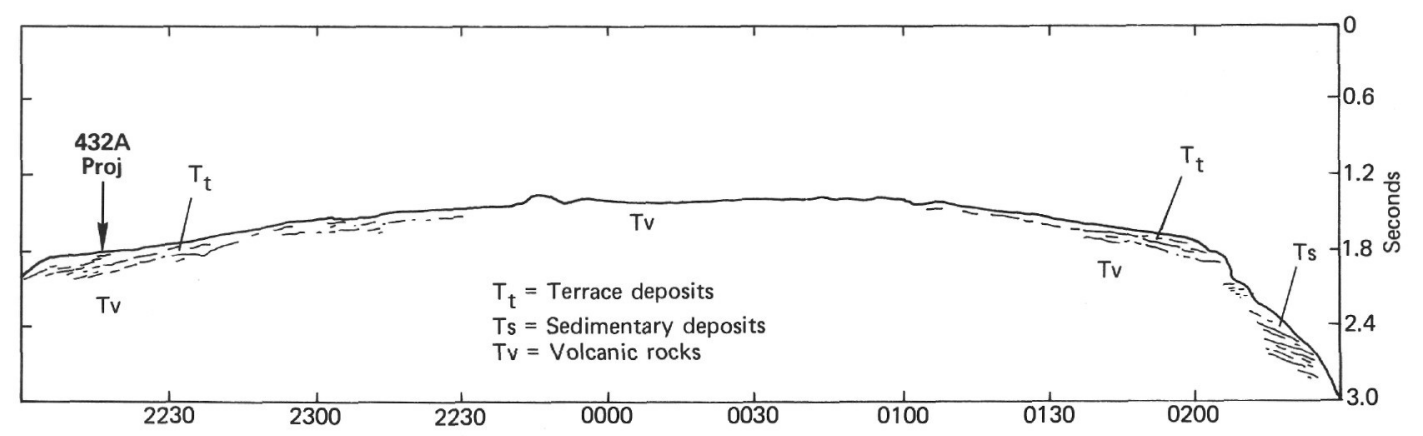

Figure 15a. Line drawing of S. P. Lee seismic reflection profile across Site 432, showing acoustic units encountered during drilling.

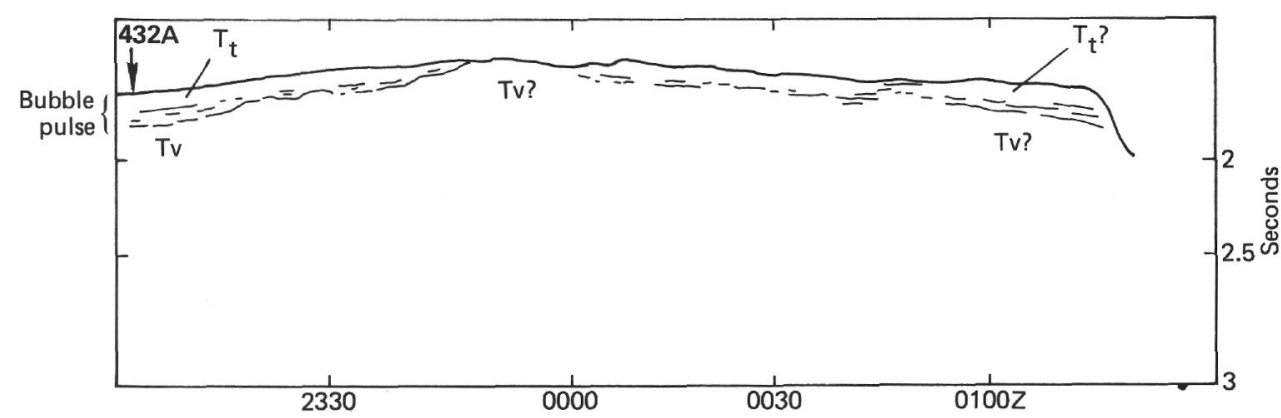

Figure 15b. Line drawing of Glomar Challenger 5-s seismic reflection profile across Site 432, showing acoustic units encountered during drilling.

zone masked by the bubble pulse. The upper 40 meters of sediment in the cores cannot be correlated with any seismic reflectors in the seismic reflection profiles. The lateritic soil or clay between Flow Units 2 and 3, at a sub-bottom depth of 45 to 55 meters, may make up the horizon that traps the seismic signal and produces the acoustic ringing (see Figure 16).

Acoustic basement in the Challenger profiles obtained upon departure from Site 432 (Figures 8 and 9) suggests a basement depth of $0.08 \mathrm{~s}(60 \mathrm{~m}$ deep at 1.5 $\mathrm{km} / \mathrm{s}$ ). In Hole 432A we encountered the tops of basalt flows that are at least 35 meters thick, at a sub-bottom depth of 55 meters.

The $3.5-\mathrm{kHz}$ profile we obtained on our approach to Site 432 shows about $0.015 \mathrm{~s}$ (approximately $40 \mathrm{~m}$ at 1.5 $\mathrm{km} / \mathrm{s}$ ) of well-layered sediments that appear fairly unconsolidated (see Figure 6). The upper 5.5 meters of this 40-meter interval probably constitutes the loosely consolidated sands and foraminiferal oozes recovered in Hole 432. All sediment between 5.5 and 39.0 meters sub-bottom in Hole $432 \mathrm{~A}$ was washed, although the driller reported resistances suggesting layering in that interval. We did not see acoustic basement in the profile.

We obtained no sonobuoy profile at this site, because acoustic basement is shallow, and the reflectors representing the stratified units are poorly defined and hidden by the bubble pulse. Seismic velocities used in interpreting the seismic reflection profiles were $1.8 \mathrm{~km} / \mathrm{s}$ for the upper 30 meters of sediments and $4.0 \mathrm{~km} / \mathrm{s}$ for the upper volcanic flow units. We calculated these velocities from the physical properties measurements of cores from Holes 432 and 432A (see above).

\section{SUMMARY AND CONCLUSIONS}

Because we were unable to drill to any appreciable depth at Site 431, which is situated on step-faulted terrace deposits and represents a change in geologic setting from Site 430 on the flat top of Ōjin Seamount, we steamed south to an alternate site on the flat top of Nintoku Seamount, in an effort to recreate our success in drilling in what appeared to be a lagoonal environment. Our first hole at Nintoku, however, proved disappointing, in that we bent and ultimately sheared off the bottom-hole assembly (BHA) at a depth of 17.5 meters; in fact, the same bottom sub failed that had sheared off at Holes 431 and 431A, again presumably because of failure of the BHA, excursion of the ship, or both. Nevertheless, we recovered 3.0 meters of light green unconsolidated pelagic sediments, consisting principally of Quaternary planktonic foraminifers deposited above the carbonate compensation depth. The total fossil assemblage suggests that the sediments were laid down by a watermass transitional between warm and cold currents.

After three nearly identical failures, we approached the drilling of Hole 432A very gingerly. The hole was washed down to the first hard material encountered (at a sub-bottom depth of $39 \mathrm{~m}$ ), so we were unable to study the intervening sedimentary rocks. But the hole did penetrate an additional 36 meters of lithified sandstone, conglomerate, and basalt before the bit stuck and the BHA broke in our attempt to pull out of the hole.

We recovered parts of three distinct basaltic flow units as well as several basalt pebbles from an overlying 


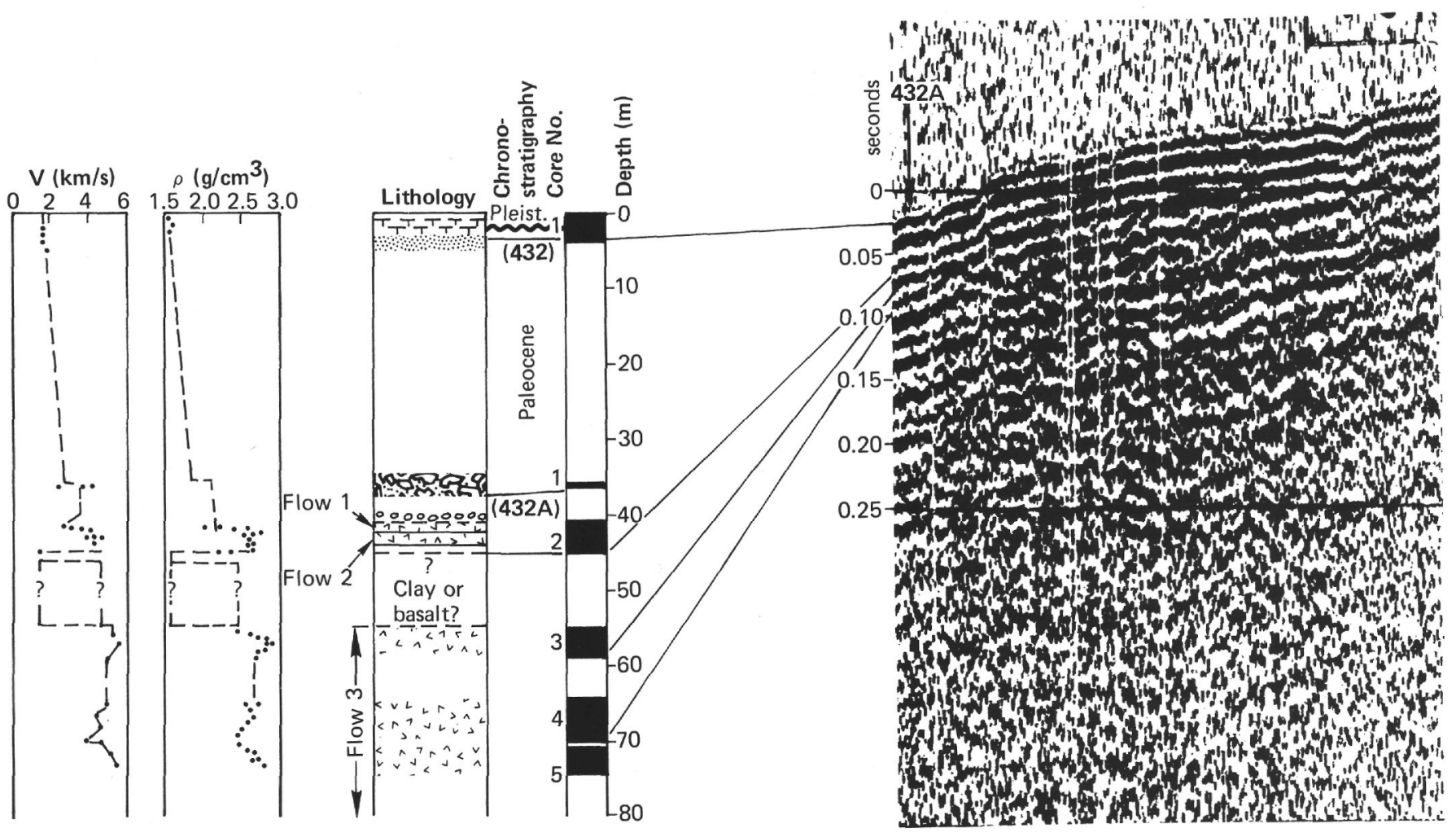

Figure 16. Correlation of seismic reflection profile with physical properties and lithologic column, Site 432.

conglomerate. Petrographic examination and chemical analyses show that the three flows are all similar to basalts of the Hawaiian alkalic suite, and probably formed during the post-caldera stage of Nintoku volcano. The uppermost two flows are feldspar phyric alkalic basalts, which, although not abundant in the Hawaiian Islands, do occur among the post-caldera alkalic basalts of Waianae volcano and immediately above the tholeiites of Kohala volcano (Macdonald and Katsura, 1964). The chemical compositions of Flow Units 1 and 2 from Hole 432A are intermediate in composition among Hawaiian feldspar phyric basalts, and probably would belong to some "middle member" of the volcanic stratigraphy of Nintoku if the entire section could be seen. The lower flow (Flow Unit 3) appears to be transitional between alkalic basalt and hawaiite, with a $\mathrm{TiO}_{2}$ content similar to the average Hawaiian alkalic basalt of Macdonald (1968), $\mathrm{Al}_{2} \mathrm{O}_{3}$ and $\mathrm{CaO}$ contents close to those of his average hawaiite, and $\mathrm{SiO}_{2}, \mathrm{MgO}$, $\mathrm{K}_{2} \mathrm{O}$, and $\mathrm{P}_{2} \mathrm{O}_{5}$ contents intermediate between these two average rock types. Among the rock types occurring as pebbles in the overlying conglomerate are alkalic basalt, hawaiite, and mugearite. No tholeiitic basalt was drilled at Site 432 .

All three flows were erupted subaerially, showing that Nintoku Seamount, like Ōjin and Suiko seamounts (Sites 430 and 433), once stood above the sea as volcanic islands. The principal indications of this are the red oxidized tops of Flow Unit 1 and, especially, of Flow Unit 3; Unit 3 is overlain by a red tropical soil at least $10 \mathrm{~cm}$ and perhaps as much as several meters thick, which could only have formed subaerially.
Although reworked and possibly deposited in a sublittoral environment, the fossiliferous volcanic sandstone and calcareous conglomerate recovered in Cores 1 and 2 of Hole 432A, directly overlying Flow Unit 1, show abundant evidence of deposition in a shallow, warm water, high-energy environment, and indicate a reef complex nearby. These sedimentary rocks appear to have been transported and deposited, in part as debris flows, in a fore-reef environment. Evidence for the existence of a reef complex includes rounded and abraded grains and pebbles of calcareous and volcanic material, algal nodules and filaments, gastropod, bryozoan, and echinoid fragments, fish debris, and worm tubes. These sediments contain larger foraminifers, planktonic foraminifers, and Paleogene, possibly Eocene(?) calcareous benthic foraminifers. Unfortunately, the fossil data accumulated on board ship did not permit a refined comparison of ages here with those of the sediments above basalt at Site 430 on Ōjin Seamount.

The basalts and sedimentary rocks from Hole 432A indicate that Nintoku Seamount had a history similar

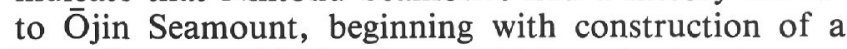
Hawaiian-type shield volcano which evolved at least to the post-caldera stage of Macdonald (1968), and which was capped with alkalic basalt and hawaiite. At one time, Nintoku stood above the sea as a volcanic island. Subsequent erosion and subsidence led to development of a reef complex such as also apparently formed on Kōkō Seamount (Larson, Moberly, et al., 1975), Ōjin Seamount (Site 430), and Suiko Seamount (Site 433). The oldest sediments recovered above basalt are Paleogene, probably Eocene, but because the interval 
from 5.5 meters (Pleistocene) to 36 meters (Eocene?) was not cored, we do not know when and under what circumstances conditions became unfavorable for reef growth. It is thus not possible to determine whether reef development on Nintoku was terminated by the onset of cold water conditions at the end of the Eocene, as suggested by Greene et al. (1978), or by subsidence or by both.

The results from Nintoku Seamount support the hotspot hypothesis, insofar as Nintoku appears to have been a typical Hawaiian volcano that once rose above the sea in warmer waters, and is probably Eocene or older. The detailed age relationships among Nintoku, Ōjin, and Kōkō could not be determined from the shipboard fossil data, but subsequent shore-based studies (Koizumi et al., this volume; Dalrymple, Lanphere and Clague, this volume) show that the age of the volcanoes increases northward, as predicted by the hot-spot hypothesis.

\section{REFERENCES}

Chase, T. E., Menard, H. W., and Mammerickx, J., 1970. Bathymetry of the North Pacific, Charts 2, 7, 8: Inst. Marine Resources, Scripps Institution of Oceanography.

Clague, D. A., 1974. The Hawaiian-Emperor Seamount chain: Its origin petrology and implications for plate tectonics, Ph.D. thesis, University of California, San Diego.
Clague, D. A., Dalrymple, G. B., and Moberly, R., 1975. Petrography and K-Ar ages of dredged volcanic rocks from the western Hawaiian Ridge and southern Emperor Seamount chain, Geol. Soc. Am. Bull., v. 86, p. 991-998.

Coe, R. S., Grommé, C. S., and Mankinen, E. A., 1978. Geomagnetic paleo-intensities from radiocarbon-dated lava flows on Hawaii and question of the Pacific nondipole low, J. Geophys. Res., v. 83, p. 1740-1756.

Cox, A. and Doell, R. R., 1964. Long period variations of the geomagnetic field, Seism. Soc. Am. Bull., p. 2243-2270.

Doell, R. R. and Cox, A., 1972. Pacific secular variation anomaly and the long-term trend in the geomagnetic field. In Robertson, E. (Ed.), The Nature of the Solid Earth, New York (McGraw Hill).

Fodor, R. V., Keil, K., and Bunch, T. E., 1975. Contributions to the mineral chemistry of Hawaiian rocks. V. Pyroxenes in rocks from Maleokala and West Maui volcanoes, Contrib. Mineral. Petrol., v. 50, p. 173-195.

Greene, H. G., Dalrymple, G. B., and Clague, D. A., 1978. Evidence for northward movement of the Emperor Seamounts, Geology, v. 6, p. 70-74.

Larson, R. L., Moberly, R., et al., 1975. Initial Reports of the Deep Sea Drilling Project, v. 32: Washington (U. S. Government Printing Office).

Macdonald, G. A., 1968. Composition and origin of Hawaiian lavas, Geol. Soc. Am. Mem. 116, p. 477-522.

Macdonald, G. A. and Katsura, T., 1964. Chemical composition of Hawaiian lavas, J. Petrol., v. 5, p. 82-133. 


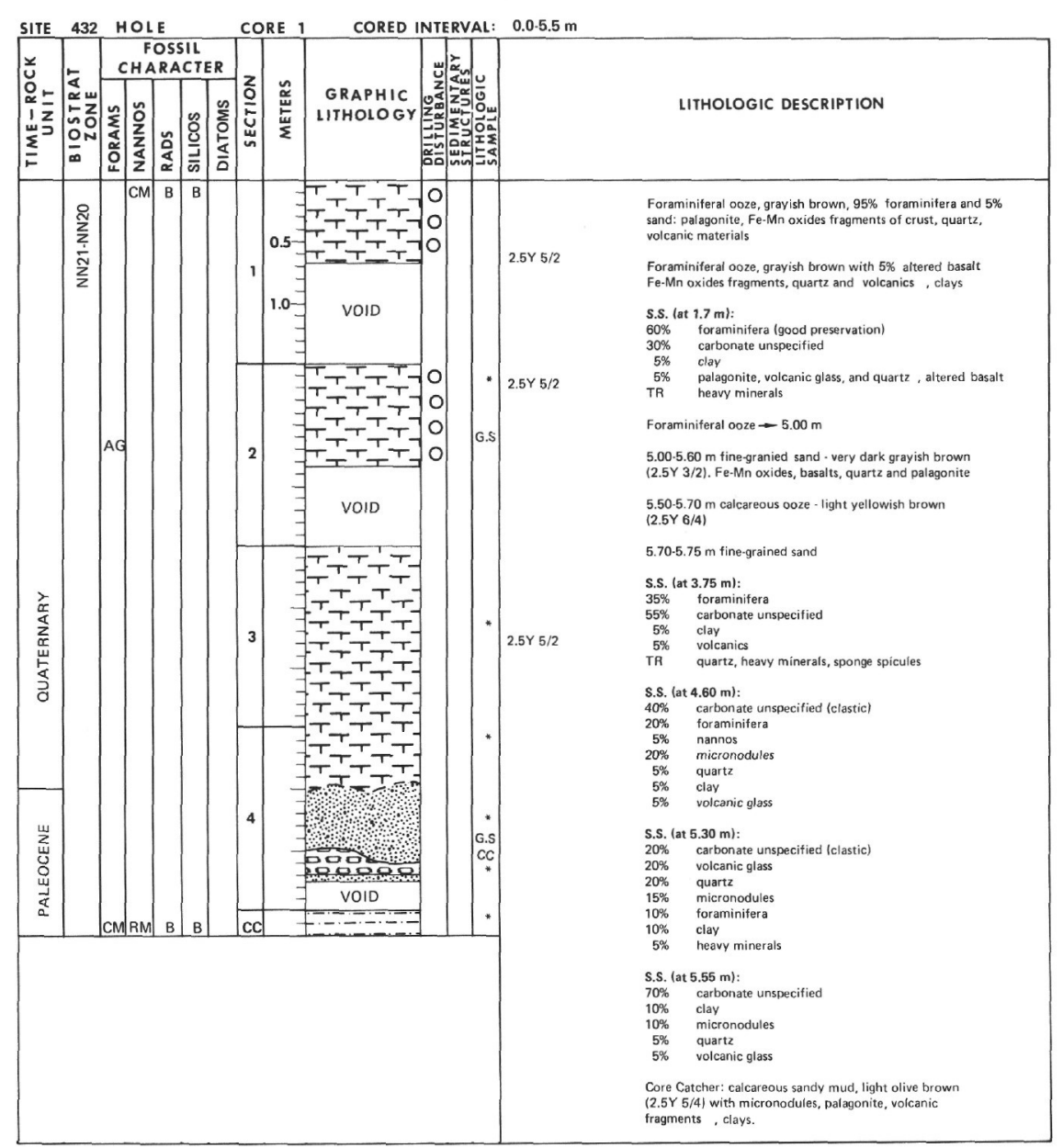




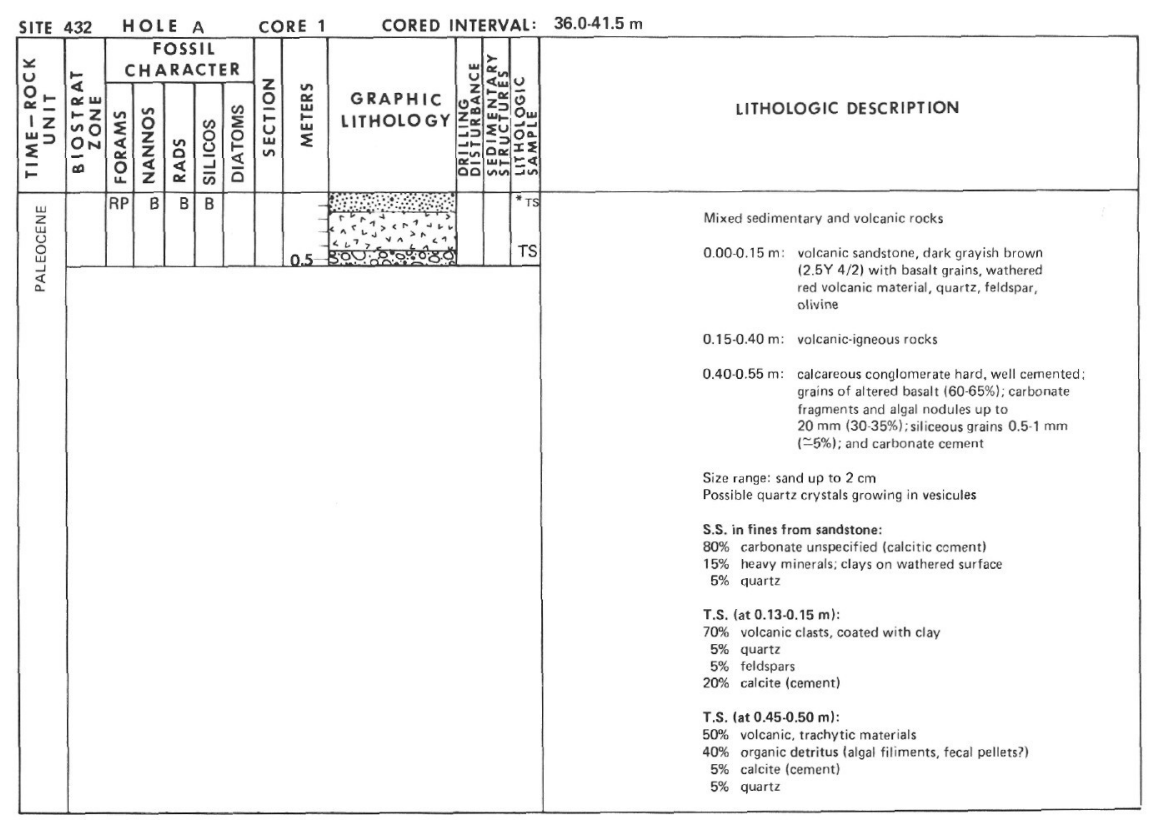

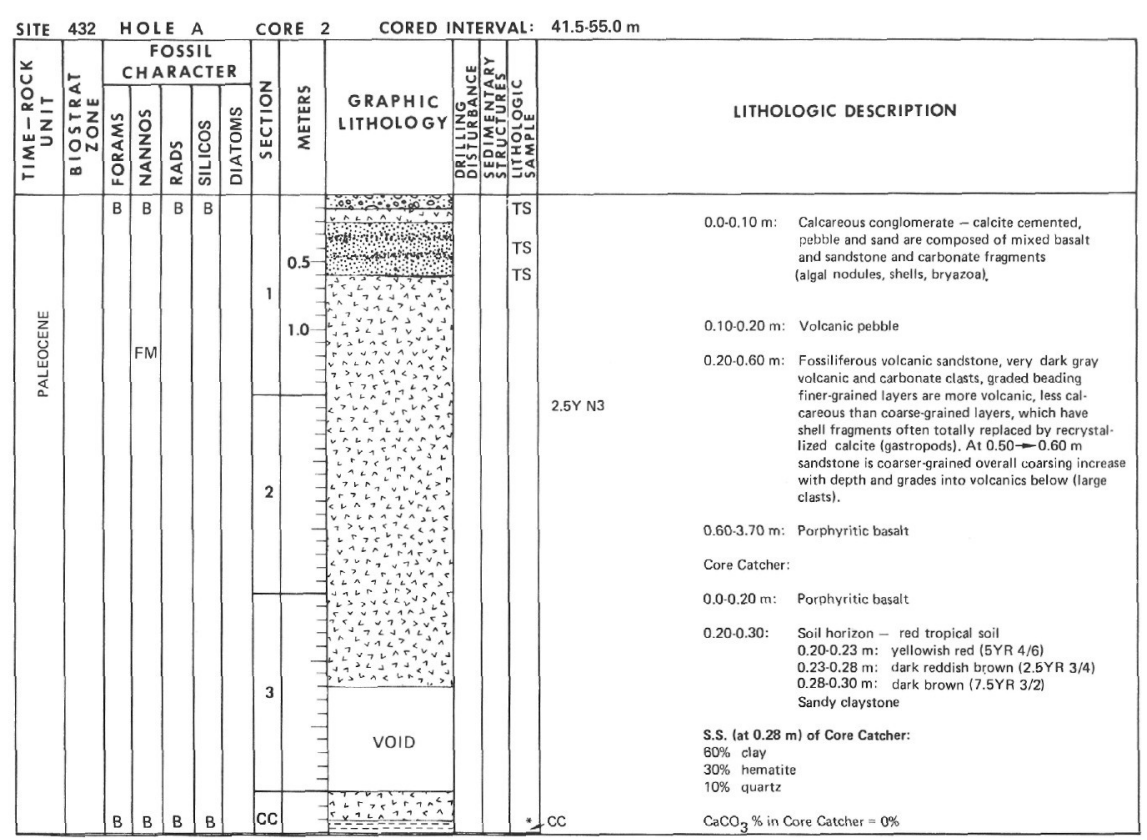


LEG 55 SITE 432 HOLE A CORE 1 DEPTH $36.0 .41 .5 \mathrm{~m}$

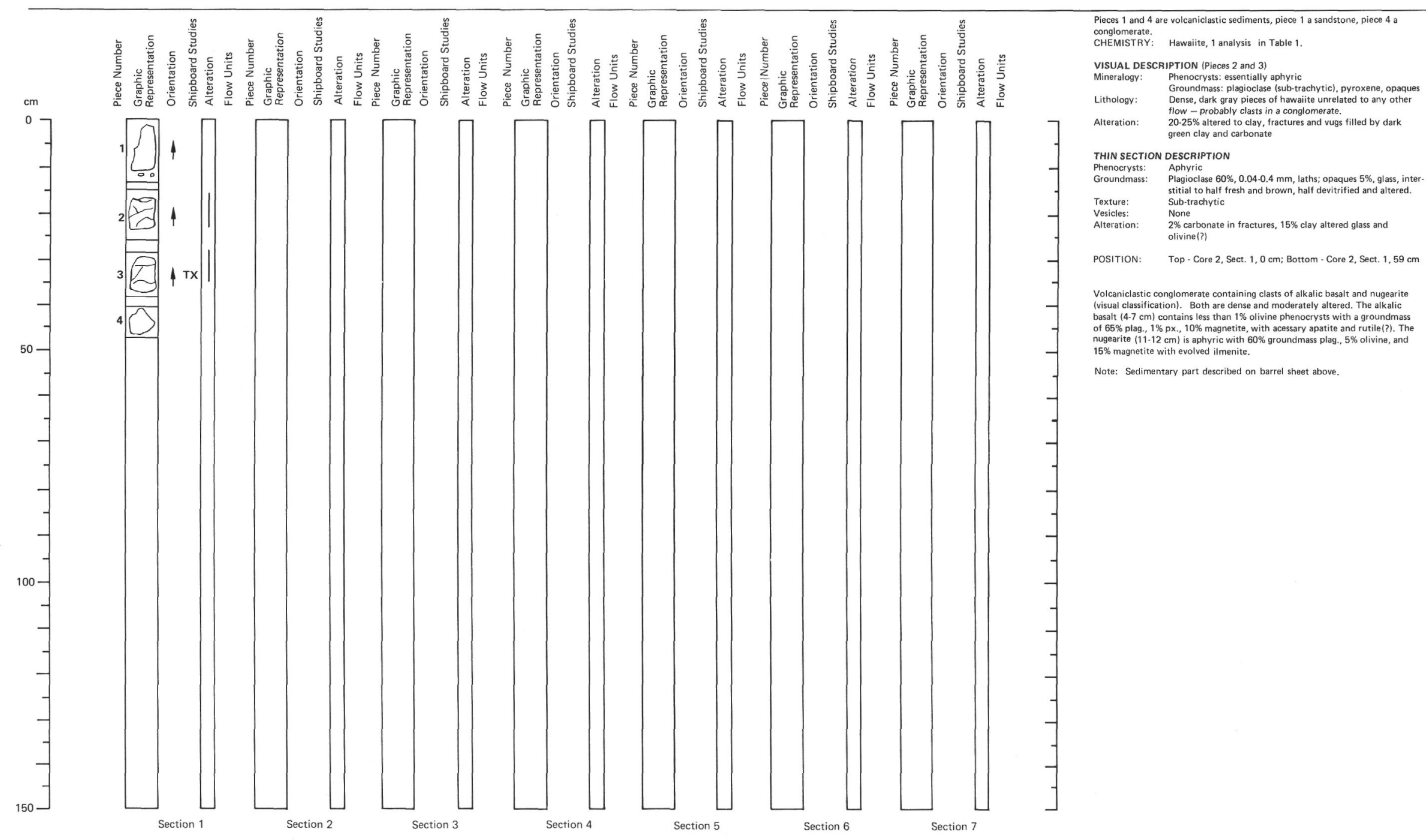


LEG 55 SITE 432 HOLE A CORE 2 DEPTH $\quad 41.5-55.0 \mathrm{~m}$

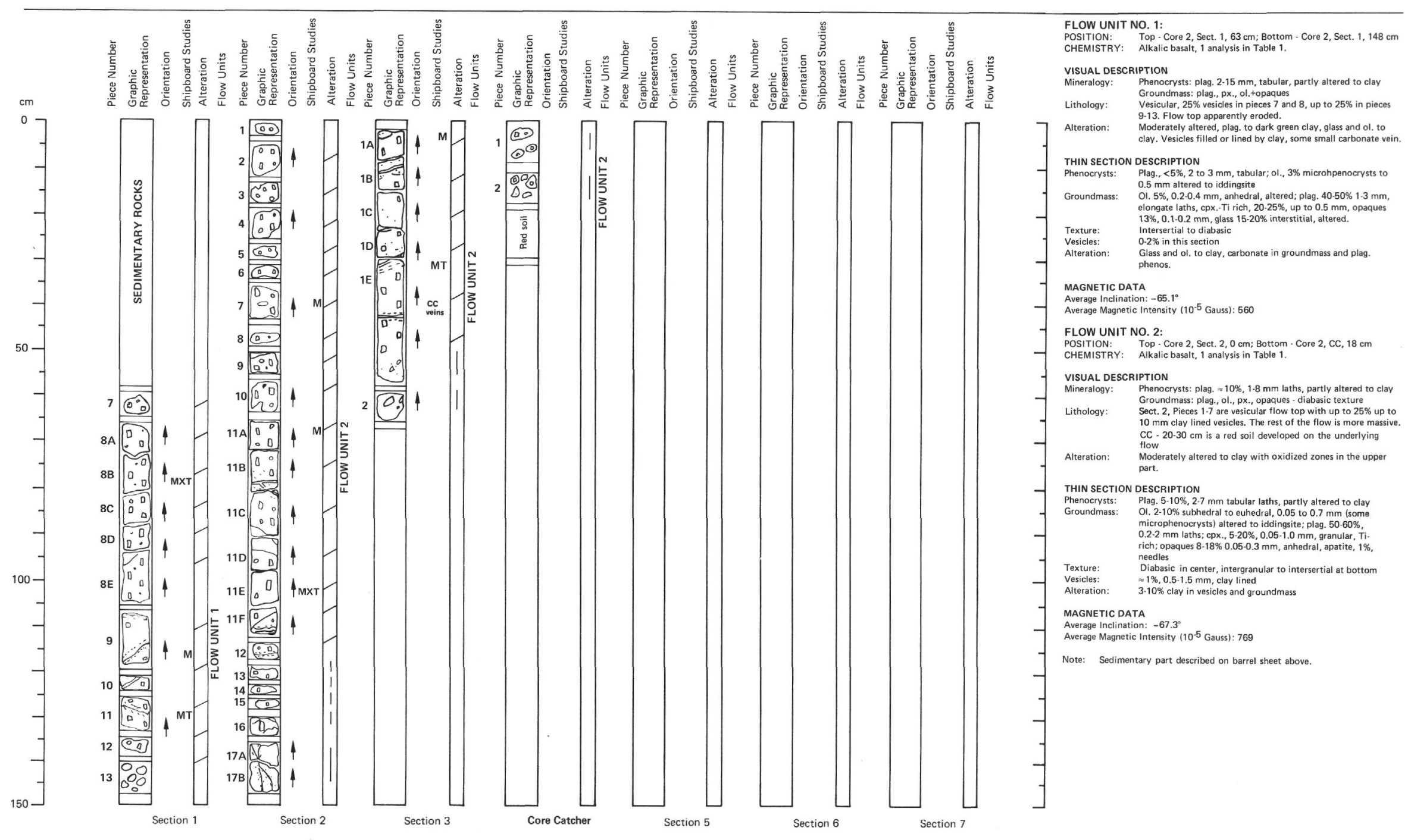




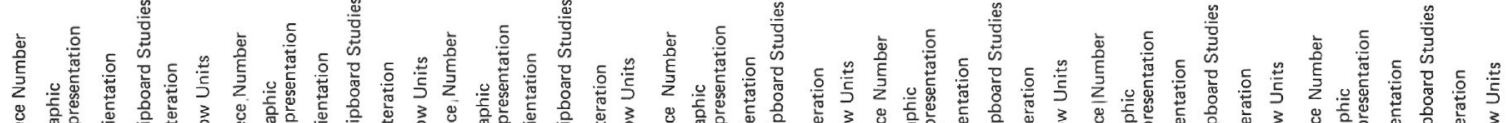

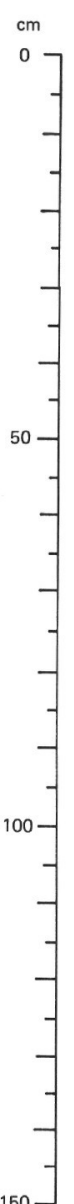

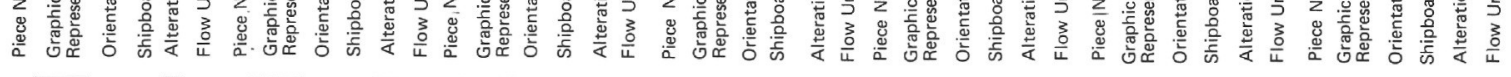
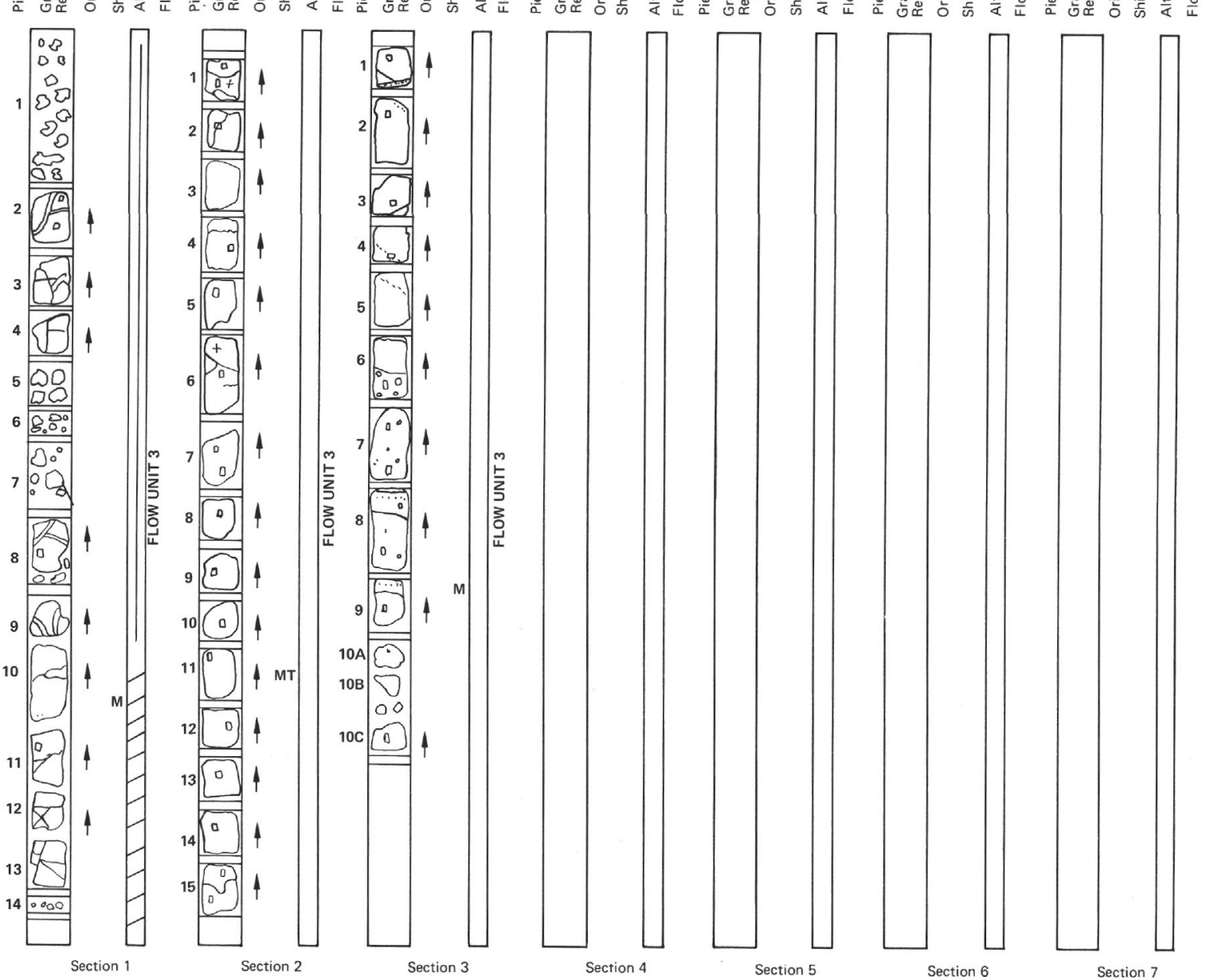

UISUAL DESCRIPTION

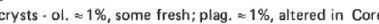
2. Section 3, px.-a very few. (progressively less oxidized downward in this section). Flow

Top is oxidized, Core 3, Section 2 to Core 4 , Section 2 are
very fresh, below this the alteration is slightly more intense.

THIN SECTION DESCRIPTION

Phenocrysts: : Oi.13\%, to $2 \mathrm{~mm}$, mostly euhedral, some fresh. Plag. <1.34

Groundmass: $\quad 01.5 \%, 0.2 \mathrm{~mm}$, subhedral to euhedral, fresh plag., $50 \%, 0$. 0.4 mm laths; c cxx. 20-25\%, anhedral-sub-ophitic; opaque.

$\begin{array}{ll}\text { Vesicles: } & 0-1 \% \text {, round, } 0.5 \text { to } 1 \mathrm{~mm} \\ \text { Alteration: } & \text { Some ol. altered to iddingsite, glass to clay, some zeolite }\end{array}$

MAGNETIC DATA

Aver age Inclination: - $28.4^{\circ}$
Average Magnetic Intensity (10.5 Gauss) : 604 


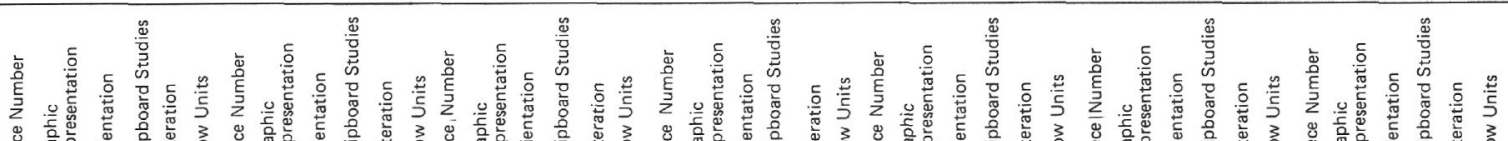

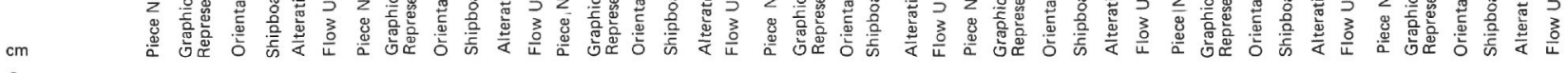

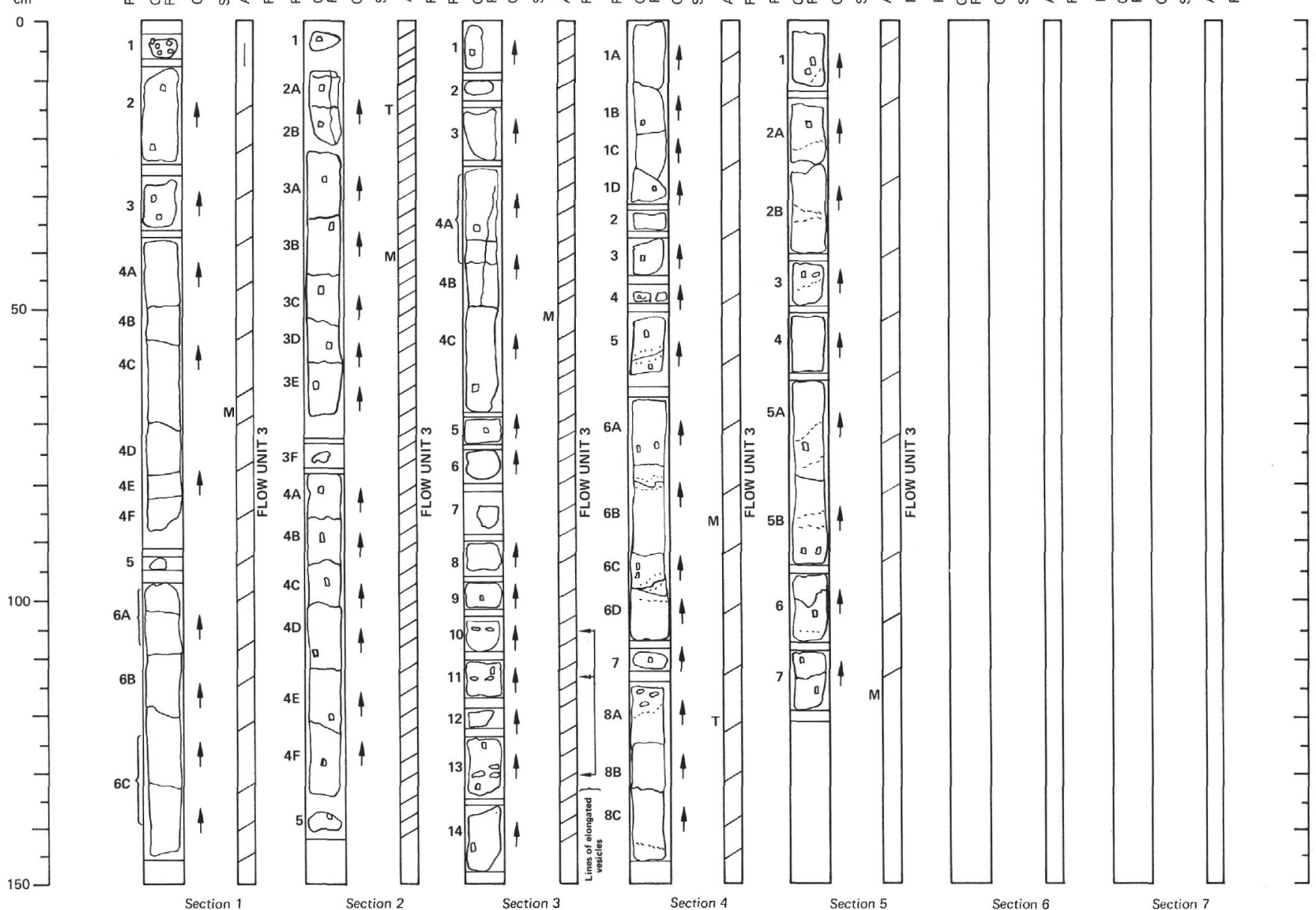




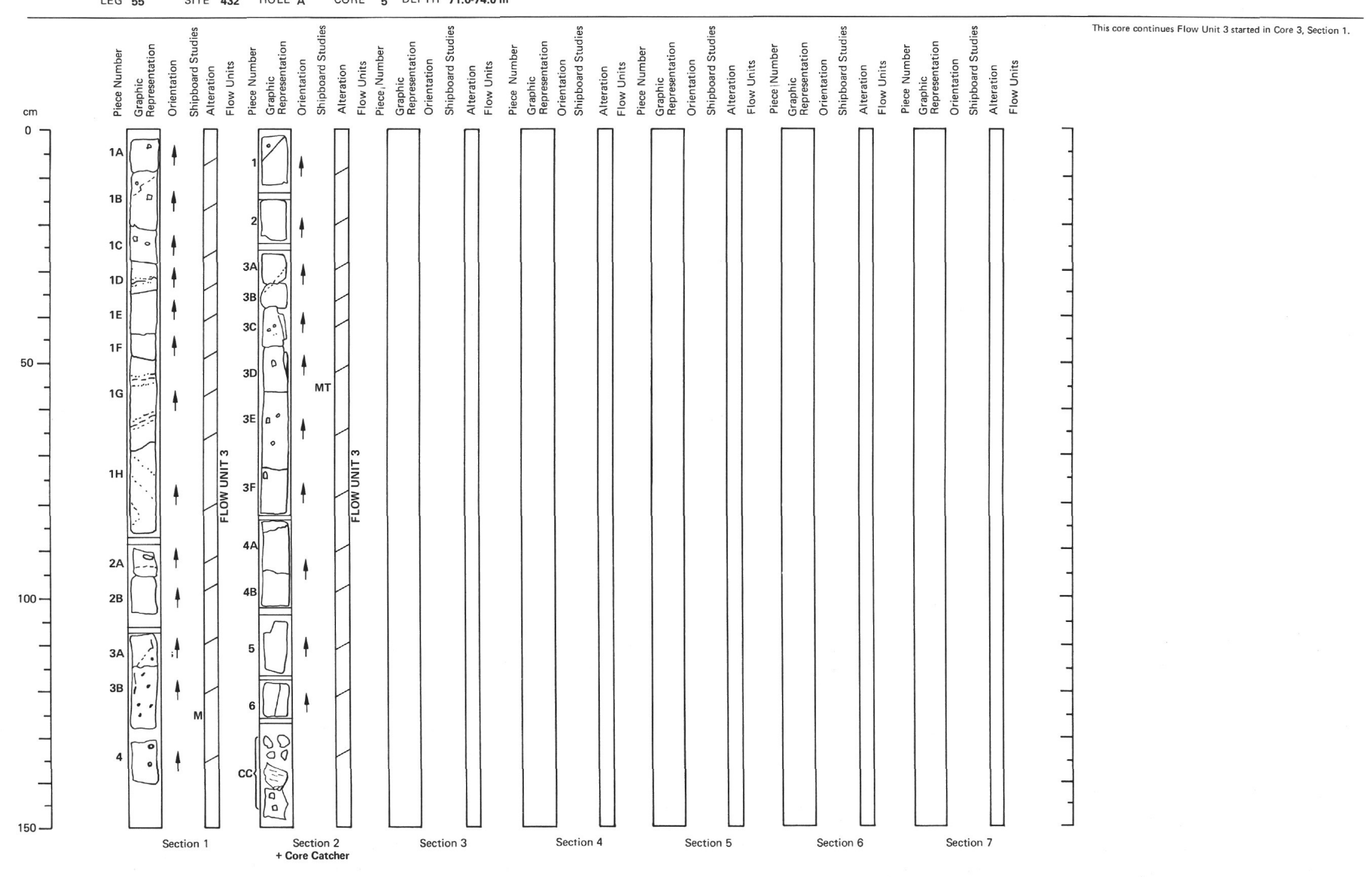


Site 432

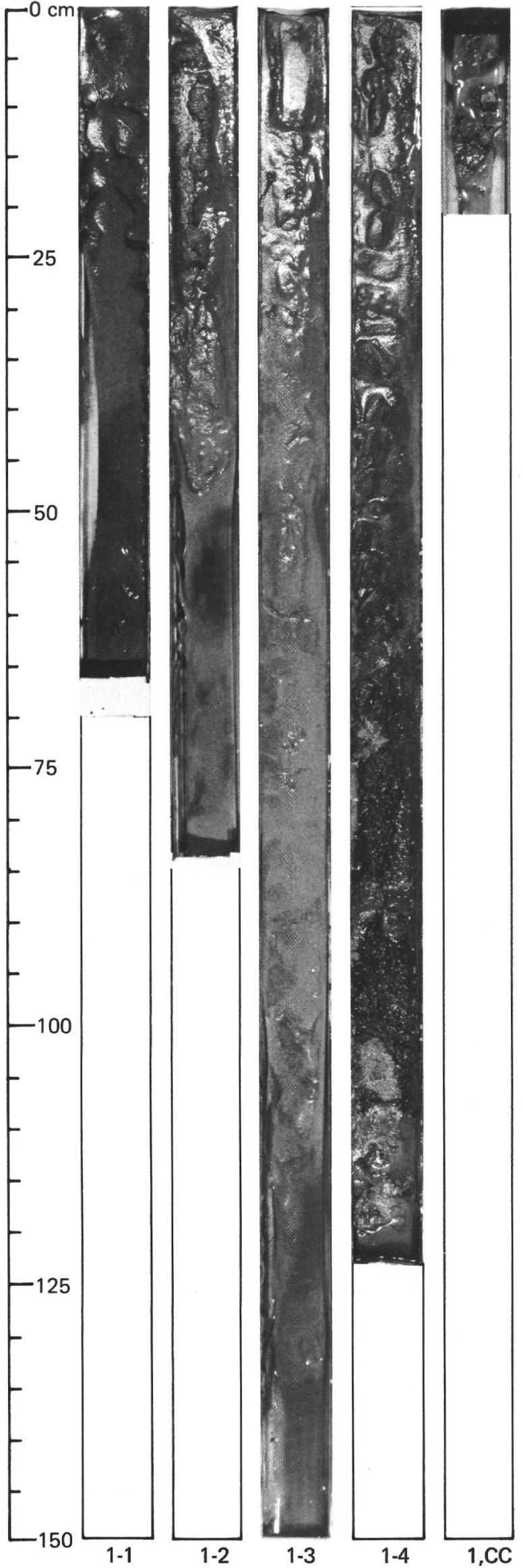

Hole 432A

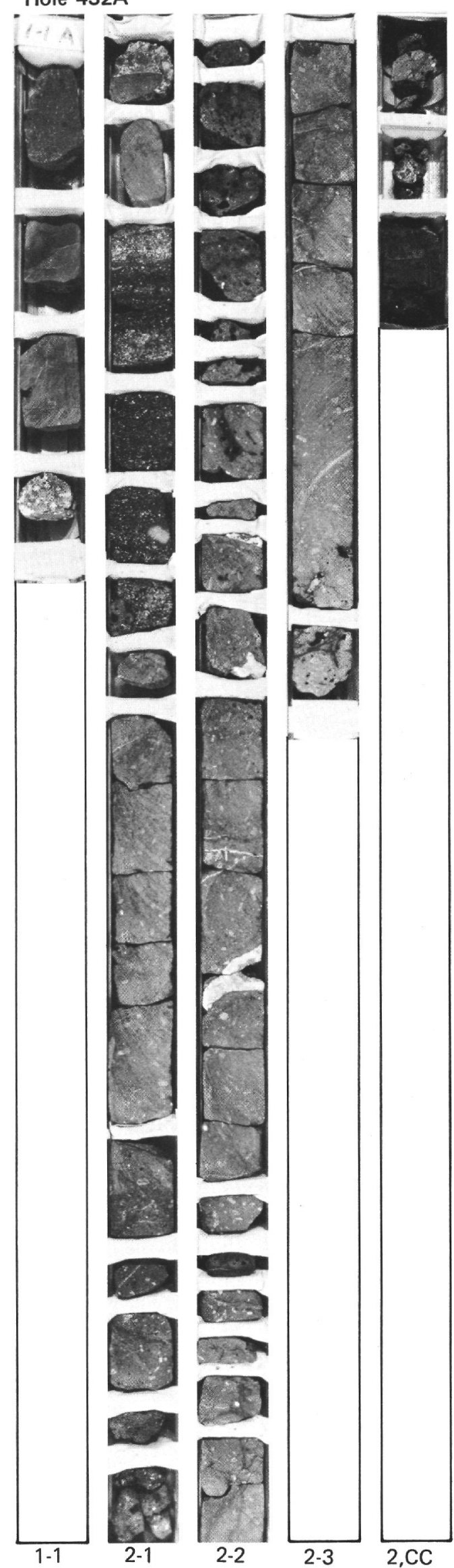


Hole 432A

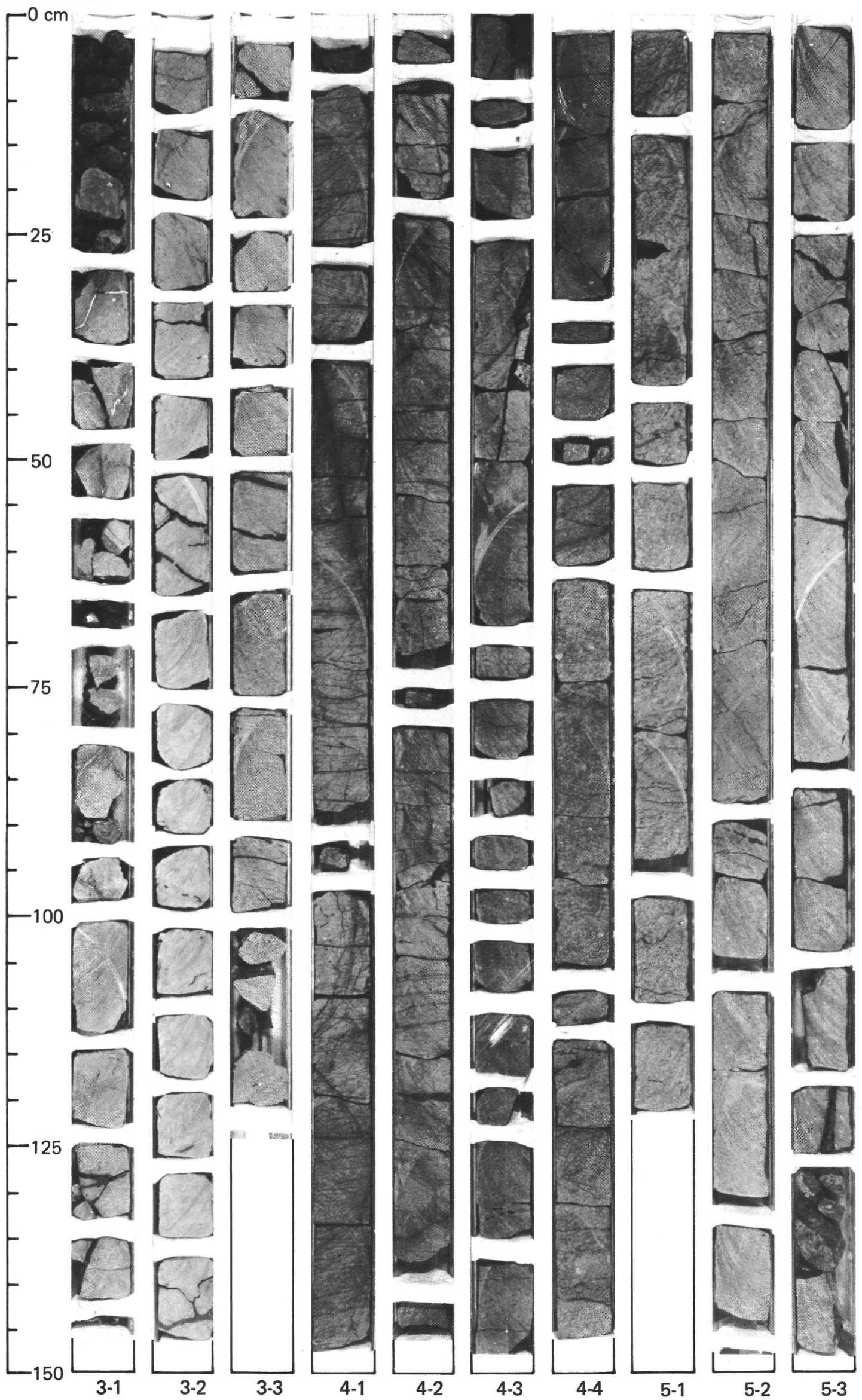

